Prepared in cooperation with the

New York City Department of Environmental Protection

\title{
Historical Water-Quality Data From the Harlem River, New York
}

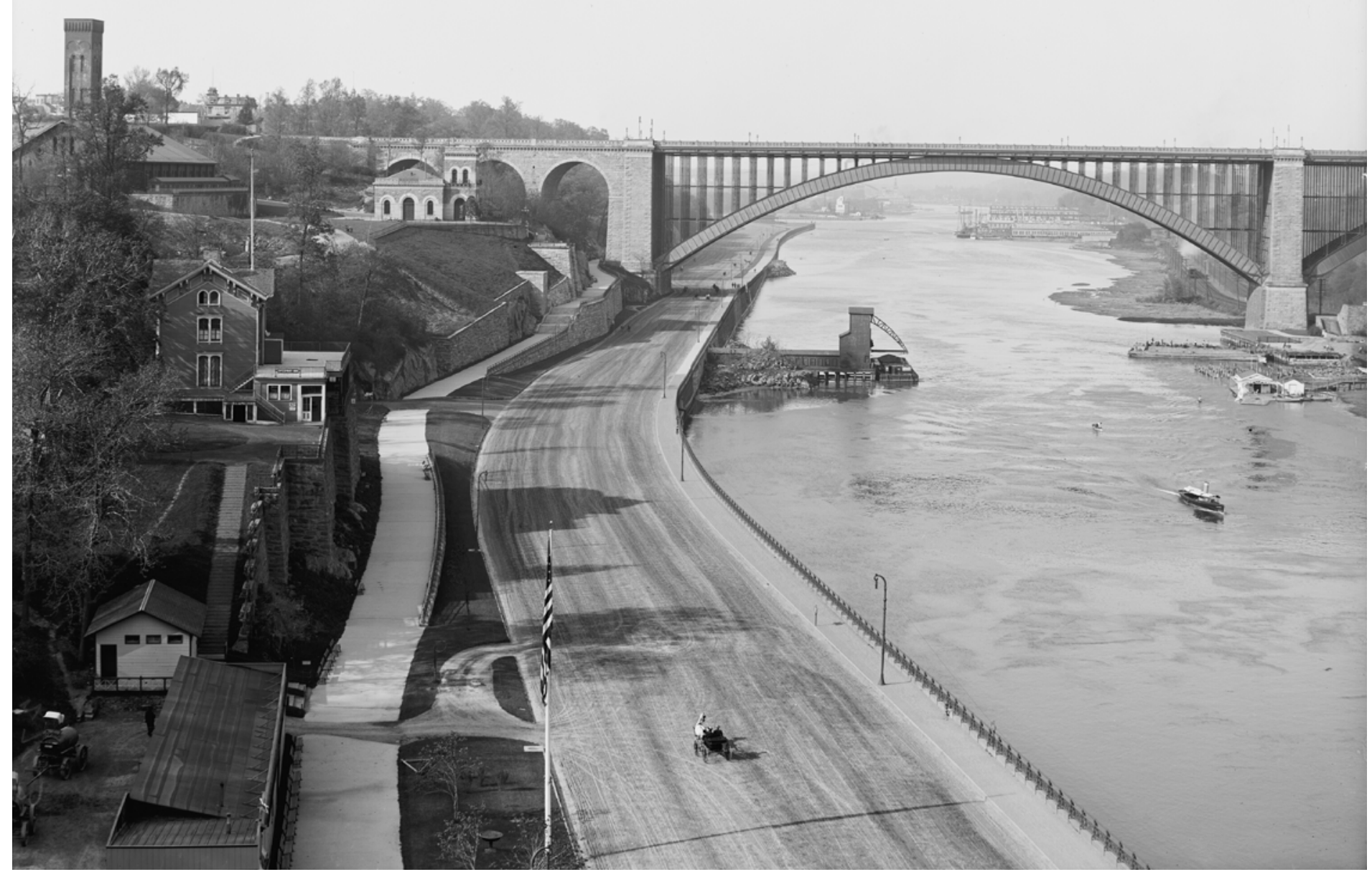

Scientific Investigations Report 2016-5044 
Cover. Photograph of the Harlem River and Washington Bridge circa 1905, looking northward. The bulkhead in place along the west riverbank (in New York County) supports the adjacent Harlem River Speedway. The east riverbank (in Bronx County) is relatively undeveloped and the shape of the bank is unaltered.

Source: Library of Congress. 


\section{Historical Water-Quality Data From the Harlem River, New York}

By Shawn C. Fisher

Prepared in cooperation with the

New York City Department of Environmental Protection

Scientific Investigations Report 2016-5044 


\title{
U.S. Department of the Interior SALLY JEWELL, Secretary
}

\section{U.S. Geological Survey Suzette M. Kimball, Director}

\author{
U.S. Geological Survey, Reston, Virginia: 2016
}

For more information on the USGS - the Federal source for science about the Earth, its natural and living resources, natural hazards, and the environment-visit http://www.usgs.gov/ or call 1-888-ASK-USGS.

For an overview of USGS information products, including maps, imagery, and publications, visit http://www.usgs.gov/pubprod/.

Any use of trade, firm, or product names is for descriptive purposes only and does not imply endorsement by the U.S. Government.

Although this information product, for the most part, is in the public domain, it also may contain copyrighted materials as noted in the text. Permission to reproduce copyrighted items must be secured from the copyright owner.

Suggested citation:

Fisher, S.C., 2016, Historical water-quality data from the Harlem River, New York: U.S. Geological Survey Scientific Investigations Report 2016-5044, 21 p., appendix, http://dx.doi.org/10.3133/sir20165044.

ISSN 2328-0328 (online) 


\section{Acknowledgments}

The author would like to thank the following for their contributions: Beau Ranheim and Kaled Alamarie of the New York City Department of Environmental Protection Bureau of Wastewater Treatment for providing the entire New York Harbor Water Quality Survey dataset and data management assistance; Lucy DiSalvo and Markus Koelbl of the New York City Department of Environmental Protection for their helpful comments in the early stages of preparing this report; and Caitlyn Nichols (formerly) of the Interstate Environmental Commission for providing reports with historical information about the Harlem River, assistance in data mining, and a technical review of an earlier draft of this report.

The author would also like to thank Patrick Phillips, John Williams, and Kenneth Pearsall of the U.S. Geological Survey for their technical review and editorial comments. 



\section{Contents}

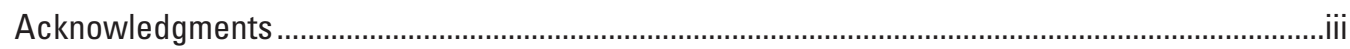

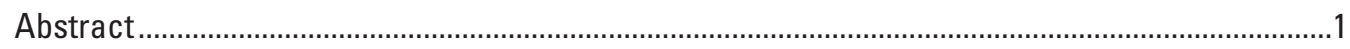

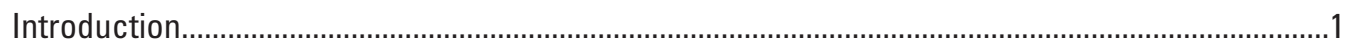

Hydrologic Setting and Historical Development of the Harlem River .....................................2

History of Environmental Quality of the Harlem River ..................................................................

Water Quality and Ecological Health................................................................................

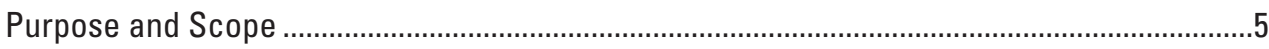

Water- and Sediment-Quality Data From the Harlem River...........................................................5

Water-Quality Parameters of Ecological Importance.............................................................

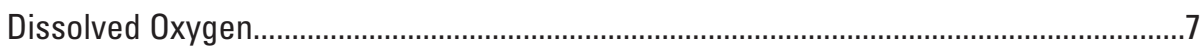

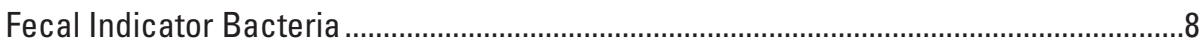

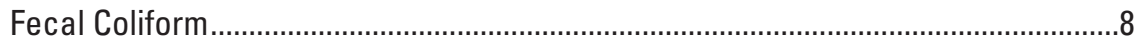

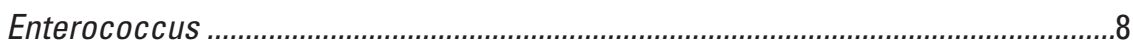

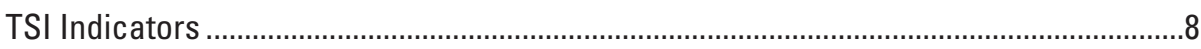

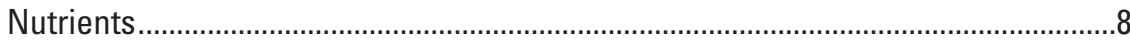

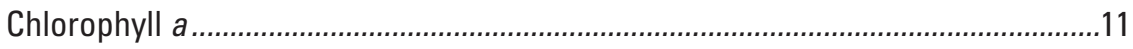

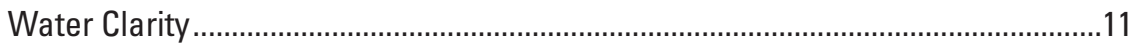

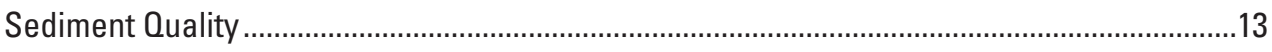

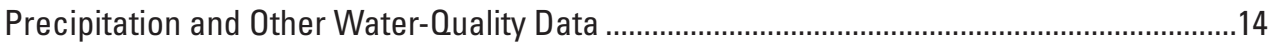

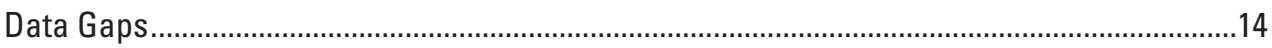

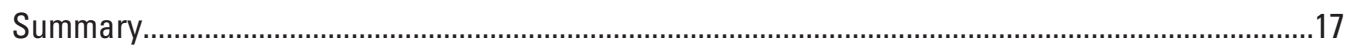

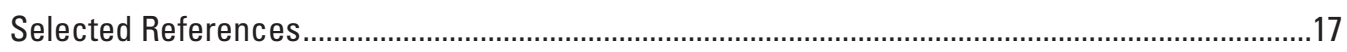

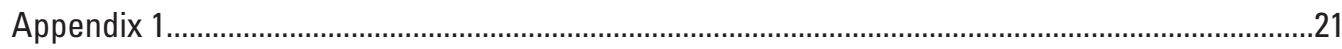

\section{Figures}

1. Map showing the Harlem River, New York, New York City Department of Environmental Protection sampling locations H1 through H5, U.S. Environmental Protection Agency Regional Environmental Monitoring Assessment Program site UH361, and the Wards Island and North River water pollution control plants

2. Map showing the Harlem River, New York, and locations of combined sewer overflow outfalls and the Wards Island water pollution control plant on the East River

3. Boxplot showing dissolved oxygen concentrations in the Harlem River, New York, from June through September, depicted in 5-year intervals: 1945-99, 2000, 2001-12.

4. Boxplot showing the geometric mean of fecal coliform concentrations in the Harlem River, New York, from June through September, depicted in 5-year

5. Boxplot showing Enterococcus concentrations at site $\mathrm{H} 3$ in the Harlem River, New York, from June through September, depicted in 5-year intervals 
6. Boxplot showing nitrate and nitrite concentrations along the Harlem River, New York, from June through September, depicted in 5-year intervals: 1987-99, 2000-12

7. Boxplot showing ammonia concentrations along the Harlem River, New York, from June through September, depicted in 5-year intervals: 1986-99, 2000-12

8. Boxplot showing orthophosphate concentrations along the Harlem River, New York, from June through September, depicted in 5-year intervals; 1986-96 and 1998-99, 2000-2008.

9. Boxplot showing chlorophyll a concentrations along the Harlem River, New York, from June through September, depicted in 5-year intervals: 1986-90 and 1992-99, 2000, 2001-12

10. Boxplot showing total suspended solids concentrations along the Harlem River, New York, from June through September, depicted in 5-year intervals: 1991-99, 2000, 2001-12

11. Boxplot showing select metals with known ecological toxicity detected in sediment samples taken from the Harlem River relative to the New York-New Jersey Harbor in 2003

12. Graph showing precipitation totals for June through September in the years that water-quality data are presented in this report.

\section{Table}

1. List of available datasets collected by Federal, State, and local agencies and organizations that include sampling locations along the Harlem River. 


\section{Conversion Factors}

\begin{tabular}{lcl}
\hline \multicolumn{1}{c}{ Multiply } & By & \multicolumn{1}{c}{ To obtain } \\
\hline inch (in.) & Length & \\
foot (ft) & 2.54 & centimeter $(\mathrm{cm})$ \\
mile (mi) & 0.3048 & meter $(\mathrm{m})$ \\
\hline & 1.609 & kilometer $(\mathrm{km})$ \\
\hline ounce, avoirdupois (oz) & Mass & \\
pound, avoirdupois (lb) & 28.35 & gram $(\mathrm{g})$ \\
& 0.4536 & kilogram $(\mathrm{kg})$ \\
\hline ounce, fluid (fl. oz) & Volume & \\
pint (pt) & 0.02957 & liter $(\mathrm{L})$ \\
quart (qt) & 0.4732 & liter $(\mathrm{L})$ \\
gallon (gal) & 0.9464 & liter $(\mathrm{L})$ \\
gallon (gal) & 3.785 & liter $(\mathrm{L})$ \\
gallon (gal) & 0.003785 & cubic meter $\left(\mathrm{m}^{3}\right)$ \\
million gallons (Mgal) & 3.785 & cubic decimeter $\left(\mathrm{dm}^{3}\right)$ \\
cubic inch (in $\left.{ }^{3}\right)$ & 3,785 & cubic meter $\left(\mathrm{m}^{3}\right)$ \\
cubic inch (in $\left.{ }^{3}\right)$ & 16.39 & cubic centimeter $\left(\mathrm{cm}^{3}\right)$ \\
cubic inch (in $\left.{ }^{3}\right)$ & 0.01639 & cubic decimeter $\left(\mathrm{dm}^{3}\right)$ \\
\hline
\end{tabular}

\section{Datum}

Horizontal coordinate information is referenced to the North American Datum of 1983 (NAD 83).

\section{Supplemental Information}

Temperature in degrees Celsius $\left({ }^{\circ} \mathrm{C}\right)$ may be converted to degrees Fahrenheit $\left({ }^{\circ} \mathrm{F}\right)$ as follows:

$$
{ }^{\circ} \mathrm{F}=\left(1.8 \times{ }^{\circ} \mathrm{C}\right)+32
$$

Concentrations of chemical constituents in water are given in either milligram per liter $(\mathrm{mg} / \mathrm{L})$ or microgram per liter $(\mu \mathrm{g} / \mathrm{L})$. 


\section{Abbreviations}

$\begin{array}{ll}\text { CSO } & \text { combined sewer overflow } \\ \text { CWA } & \text { Clean Water Act } \\ \text { EPA } & \text { U.S. Environmental Protection Agency } \\ \text { HRECOS } & \text { Hudson River Environmental Conditions Observation System } \\ \text { NWS } & \text { National Weather Service } \\ \text { NWIS } & \text { National Water Information System } \\ \text { NYCDEP } & \text { New York City Department of Environmental Protection } \\ \text { NYSDEC } & \text { New York State Department of Environmental Conservation } \\ \text { PAH } & \text { polycyclic aromatic hydrocarbon } \\ \text { PCB } & \text { polychlorinated biphenyl } \\ \text { REMAP } & \text { Regional Environmental Monitoring Assessment Program } \\ \text { SVOC } & \text { semivolatile organic compound } \\ \text { TMDL } & \text { total maximum daily load } \\ \text { TSI } & \text { trophic state index } \\ \text { USGS } & \text { U.S. Geological Survey } \\ \text { UWFP } & \text { Urban Waters Federal Partnership } \\ \text { VOC } & \text { volatile organic compound } \\ \text { WPCP } & \text { water pollution control plant }\end{array}$




\title{
Historical Water-Quality Data From the Harlem River, New York
}

\author{
By Shawn C. Fisher
}

\section{Abstract}

Data specific to the Harlem River, New York, have been summarized and are presented in this report. The data illustrate improvements in the quality of water for the past 65 years and emphasize the importance of a continuous water-quality record for establishing trends in environmental conditions. Although there is a paucity of sediment-quality data, the New York City Department of Environmental Protection (NYCDEP) Bureau of Wastewater Treatment has maintained a water-quality monitoring network in the Harlem River (and throughout the harbor of New York City) to which 61 combined sewer outfalls discharge effluent. In cooperation with the NYCDEP, the U.S. Geological Survey evaluated water-quality data collected by the NYCDEP dating back to 1945 , which indicate trends in water quality and reveal improvement following the 1972 passage of the Clean Water Act. These improvements are indicated by the steady increase in median dissolved oxygen concentrations and an overall decrease in fecal indicator bacteria concentrations starting in the late 1970s. Further, the magnitude of the highest fecal indicator bacteria concentrations (that is, the 90th percentile) in samples collected from the Harlem River have decreased significantly over the past four decades. Other parameters of water quality used to gauge the health of a water body include total suspended solids and nutrient (inorganic forms of nitrogen and phosphorus) concentrations - mean concentrations for these indicators have also decreased in the past decades. The limited sediment data available for one sample in the Harlem River indicate concentrations of copper, zinc, and lead are above sediment-quality thresholds set by the New York State Department of Environmental Conservation. However, more data are needed to better understand the changes in both sediment and water quality in the Harlem River, both as the tide cycles and during precipitation events. As a partner in the Urban Waters Federal Partnership, the U.S. Geological Survey has worked to address the chronic water-quality concerns of the Harlem River by compiling relevant data and studies, which is an important component for understanding and rectifying water-quality problems within a watershed.

\section{Introduction}

The Harlem River (New York City, New York) has provided the neighboring urban communities with recreational opportunities like boating and fishing since the 1700s. Over time, human activities along the Harlem River, such as shipping, industry, and waste disposal, have severely affected the overall water quality of the river. Since the late 1800 s, data specific to the estuarine waters of New York City have been collected by the New York City Department of Environmental Protection (NYCDEP) for an increasing number of physical and chemical water-quality parameters in an attempt to better understand these human effects on the ecological health of the waterways around New York City (New York City Department of Environmental Protection, [2010]). This monitoring has been maintained throughout the 1900s to the present day (2016) and provides an important record of water-quality data that can be interpreted along with other discrete and continuously collected data to identify changes in human activities throughout the years.

There is a need for publically available data that adequately describe the water-quality and ecological conditions of the Harlem River. The New York State Department of Environmental Conservation (NYSDEC) continues to designate the Harlem River as a "Class I" river, which means that the communities surrounding the river cannot fully utilize their natural resource. Without more data to better understand the sediment and water quality in the river (during the tidal cycles and precipitation events, for example), the fate and transport of contaminants and extent to which they affect the river cannot be fully known or addressed. As a partner in the Urban Waters Federal Partnership (UFWP), the U.S. Geological Survey (USGS) continues to work with other agencies and community partners to address the chronic water-quality concerns of the Harlem River by compiling relevant data and studies, which makes information available to communities and aides in understanding and rectifying water-quality problems within the Harlem River and neighboring waterways. 
The USGS, in cooperation with the NYCDEP Bureau of Wastewater Treatment, compiled water-quality data and evaluated the ecologically relevant trends of the Harlem River, because assessing available relevant data is an important step towards the ultimate goal of revitalizing urban waterways (U.S. Environmental Protection Agency, [2014b]). Historical data between 1945 and 2012 were evaluated to help identify the changes in practice or management that contributed to improved water quality and those conditions where waterquality issues remain. An outline of these and other available data are provided in table 1. Data from historical water- and sediment-monitoring programs are important to preserve electronically so data can be available to provide stakeholders the tools to make informed decisions about the resources of the Harlem River.

The assessment and compilation of data for this effort also supports the UWFP, a nationwide initiative to provide local communities with an opportunity to invest and participate in restoring their local waterways (U.S. Environmental Protection Agency, 2011). The initiative was launched by the White House Office of Urban Affairs and the U.S. Environmental Protection Agency (EPA) in 2011 to encourage government agencies to work closely with the communities to revitalize the Nation's polluted and underutilized urban waterways. The Harlem River was one of the first seven urban waters to be named to the program and the USGS has taken a proactive role in studying many of the streams and watersheds in the program. The guiding principles of the UWFP state that the work conducted by Federal agencies should assist in the following activities whenever possible: promote clean urban waters, reconnect people to their waterways, conserve water, use waterways to promote economic development, encourage community participation, be open and honest while engaging communities, and focus on measuring results. Community groups, volunteers, and State and local governments are teaming up with a number of Federal agencies to develop and implement changes needed to bring about an improvement in water quality, better access to the Harlem River, "green" facilities and parks along the riverfront, and a sense of community that will stimulate environmental awareness and economic growth.

\section{Hydrologic Setting and Historical Development of the Harlem River}

Bounded by New York and Bronx Counties, the Harlem River is an 8-mile tidal strait that connects the Hudson River and East River (fig. 1). The Harlem River is just one of the waterways surrounding New York City, including Upper Bay,

Table 1. List of available datasets collected by Federal, State, and local agencies and organizations that include sampling locations along the Harlem River.

[Physical parameters may include any of the following: water temperature, dissolved oxygen, salinity, $\mathrm{pH}$, turbidity (water clarity), or chlorophyll $a$. SW, surface water; GW, groundwater; PCBs, polychlorinated biphenyls; PAHs, polycyclic aromatic hydrocarbons; SVOCs, semivolatile organic compounds; VOCs, volatile organic compounds. The term "present" refers to the status as of 2016. Data availability: $a$, http://nwis.waterdata.usgs.gov/nwis/qwdata; $b$, http://www.riverkeeper.org/water-quality/hudson-river/\#map]

\begin{tabular}{|c|c|c|c|c|c|}
\hline Agency/group & Medium & Data collected & $\begin{array}{c}\text { Harlem River } \\
\text { sample } \\
\text { location(s) }\end{array}$ & Period of record & $\begin{array}{c}\text { Data } \\
\text { availability }\end{array}$ \\
\hline \multirow[t]{2}{*}{$\begin{array}{l}\text { New York City Department of } \\
\text { Environmental Protection }\end{array}$} & SW & Physical parameters & 5 sites $(\mathrm{H} 1-\mathrm{H} 5)$ & $\begin{array}{l}\text { 1909-73 } \\
\quad \text { (June-October) }\end{array}$ & Table $1-1$ \\
\hline & & $\begin{array}{l}\text { Physical parameters, nutrients, fecal } \\
\text { coliform and (or) Enterococcus }\end{array}$ & 5 sites $(\mathrm{H} 1-\mathrm{H} 5)$ & $\begin{array}{l}\text { 1974-2000 } \\
\quad \text { (year-round) }\end{array}$ & Table 1-1 \\
\hline \multirow[t]{2}{*}{$\begin{array}{l}\text { U.S. Environmental Protection } \\
\text { Agency }\end{array}$} & Sediment & $\begin{array}{l}\text { Metals, PCBs, PAHs, pesticides, } \\
\text { dioxins/furans }\end{array}$ & UH361 & 2003 & Table $1-2$ \\
\hline & SW & Physical parameters & & & Table $1-3$ \\
\hline $\begin{array}{l}\text { New York State Department of } \\
\text { Environmental Conservation }\end{array}$ & Sediment & Metals, PCBs, pesticides, PAHs & 6 sites & 2000 & Table $1-5$ \\
\hline Riverkeeper, Inc. & SW & Physical parameters, Enterococcus & 2 sites & $\begin{array}{l}\text { 2006-present } \\
\quad \text { (May-October) }\end{array}$ & $b$ \\
\hline National Weather Service & Precipitation & Precipitation amounts (daily totals) & Central Park, N.Y. & 1876-present & Table $1-7$ \\
\hline
\end{tabular}




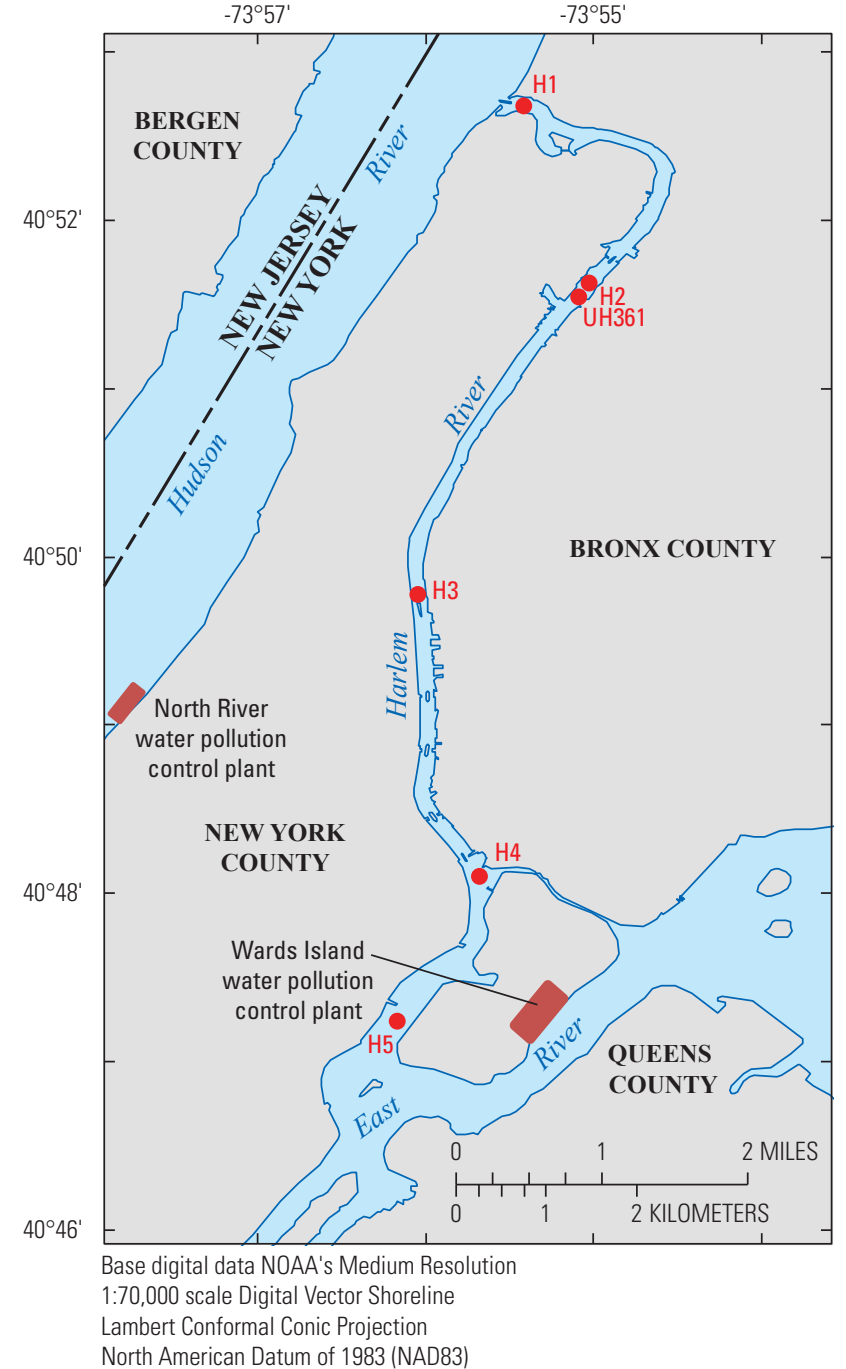

The Narrows, and Lower Bay, that will collectively be referred to as the "Harbor" in this report. The Harbor is considered an estuary that receives seawater from the Atlantic Ocean and Long Island Sound, and freshwater from the five counties of New York City and New Jersey, and the Hudson River. Blumberg and others (1999) estimated the net flow to be 10 cubic meters per second $\left(\mathrm{m}^{3} / \mathrm{s}\right)$ northward from the ocean through the East River and New York Bight.

Before urban expansion in the 1800s, the Harlem River received freshwater inputs from groundwater-fed tributaries along both shores. The rapid development of New York City led to the filling of these creeks and tributaries. Groundwater that once fed these springs and creeks is now pumped and diverted to avoid the flooding of subterranean infrastructure (Metropolitan Transit Authority, 2012). The Harlem River was widened to facilitate commercial traffic and barges, which required dredging and shoreline hardening (bulkheads, for example) that led to a reshaping of the river from its natural course. The Manhattan project and New York City OASIS

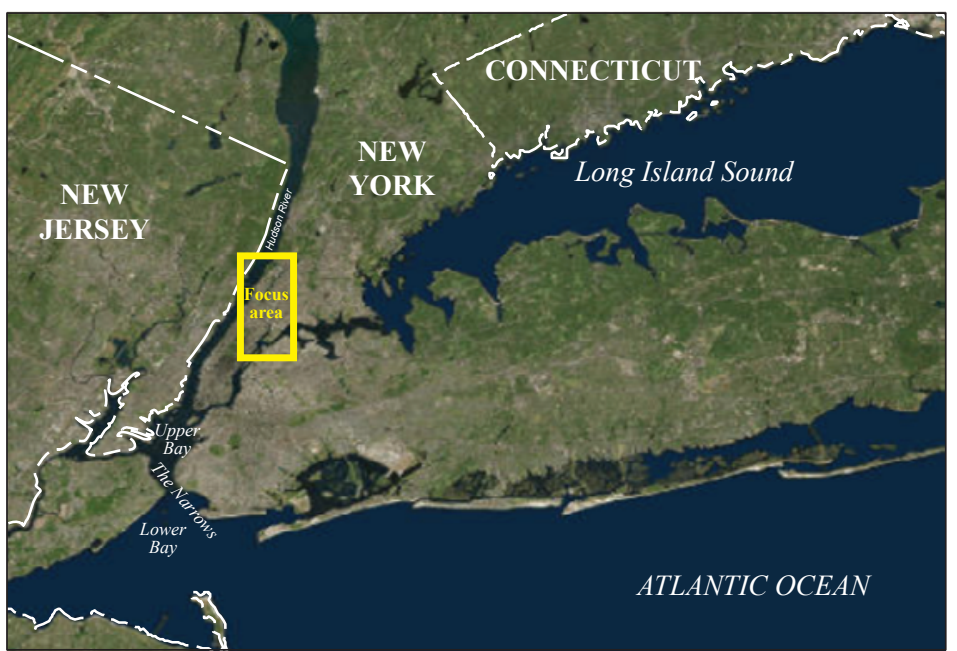

Base from Esri, DigitalGlobe, GeoEye, i-cubed, Earthstar Geographics, CNES/Airbus DS, USDA, USGS, AEX, Getmapping, Aerogrid, IGN, IGP, swisstopo, and the GIS User Community

Figure 1. The Harlem River, New York, New York City Department of Environmental Protection sampling locations $\mathrm{H} 1$ through H5, U.S. Environmental Protection Agency Regional Environmental Monitoring Assessment Program site UH361, and the Wards Island and North River water pollution control plants.

map provide modeled depictions of the area in pre-settlement around 1609 (City University of New York, 2014). The New York City Oasis interactive map also offers many layers representing socioeconomic, municipal, and community attributes that can be used to better understand potential sources of contaminants and the effect of remediation projects.

\section{History of Environmental Quality of the Harlem River}

As New York City became more populated, water quality in the adjacent harbors, bays, and rivers began to decline. Untreated wastewater and stormwater runoff would enter the Harlem River and the rest of the Harbor, resulting in foul smells and conditions unfit for human contact (New York City Department of Environmental Protection, [2010]). Accompanying fish kills also became an issue because of low concentrations of dissolved oxygen and plumes of harmful bacteria associated with the discharge of raw sewage. By 
1910, the Harbor was so ecologically impaired that a panel of scientists and engineers presented data on the state of the waters and made recommendations for major improvements to the city sewer system (Soper and others, 1910).

As treatment technology became more advanced, construction of sophisticated sewer systems throughout the 20th Century helped divert wastewater, which had been discharging to nearby waterways, to water pollution control plants (WPCPs) for processing (Soper and others, 1910; New York City Department of Environmental Protection, [2013]). These WPCP systems collected sanitary sewage along with rainwater from storm drains and are, therefore, called a combined sewer system. Under nonstorm conditions, the early WPCPs were capable of processing and treating volumes associated with the estimated sewage loads that entered the system; during storms, however, the WPCPs were frequently unable to process the increased volumes of mixed sewage and surface runoff, and the excess had to be diverted away from the plant. This is known as combined sewer overflow (CSO), which results in the discharge of untreated wastewater to nearby waterways, such as the Harlem River. These CSO events (U.S. Environmental Protection Agency, [2014a]) introduce pathogenic bacteria and other contaminants associated with sewage directly to the waters along the sewer flow path to the WPCPs.

There are $61 \mathrm{CSO}$ outfalls along the banks of the Harlem River (fig. 2) that can potentially discharge untreated wastewater during storms. Until the 1970s, the New York City WPCPs were not able to accommodate much additional volume beyond the sewage component, such that even the slightest rainfall (sometimes as low as 0.1 inch) would cause the WPCP to be bypassed and untreated wastewater discharged to the Harbor (New York City Department of Environmental Protection, [2013]). Improvements to wastewater processing and management practices spurred by the Clean Water Act (CWA) passed by Congress in 1972 resulted in a total of 14 WPCPs in New York City capable of handling most of the wastewater that enters the system, including greater volumes of stormwater before diverting to a CSO. The steady decrease in the amount of untreated sewage and surface runoff entering adjacent waters has led to improvements in the water quality over the past 40 years (for example, overall lower levels of pathogens and higher dissolved oxygen concentrations; New York City Department of Environmental Protection, [2010]).

\section{Water Quality and Ecological Health}

Point sources (such as WPCPs) and nonpoint sources (such as stormwater runoff) of contaminants contribute to the water quality, and thus the ecological health, of an estuary or waterway. Point sources to the Harlem River include the North River WPCP and the Wards Island WPCP (fig. 1), which discharge millions of gallons per day of treated wastewater to the Hudson River and East River (respectively). Wastewater discharge from CSO outfalls directly to the Harlem River

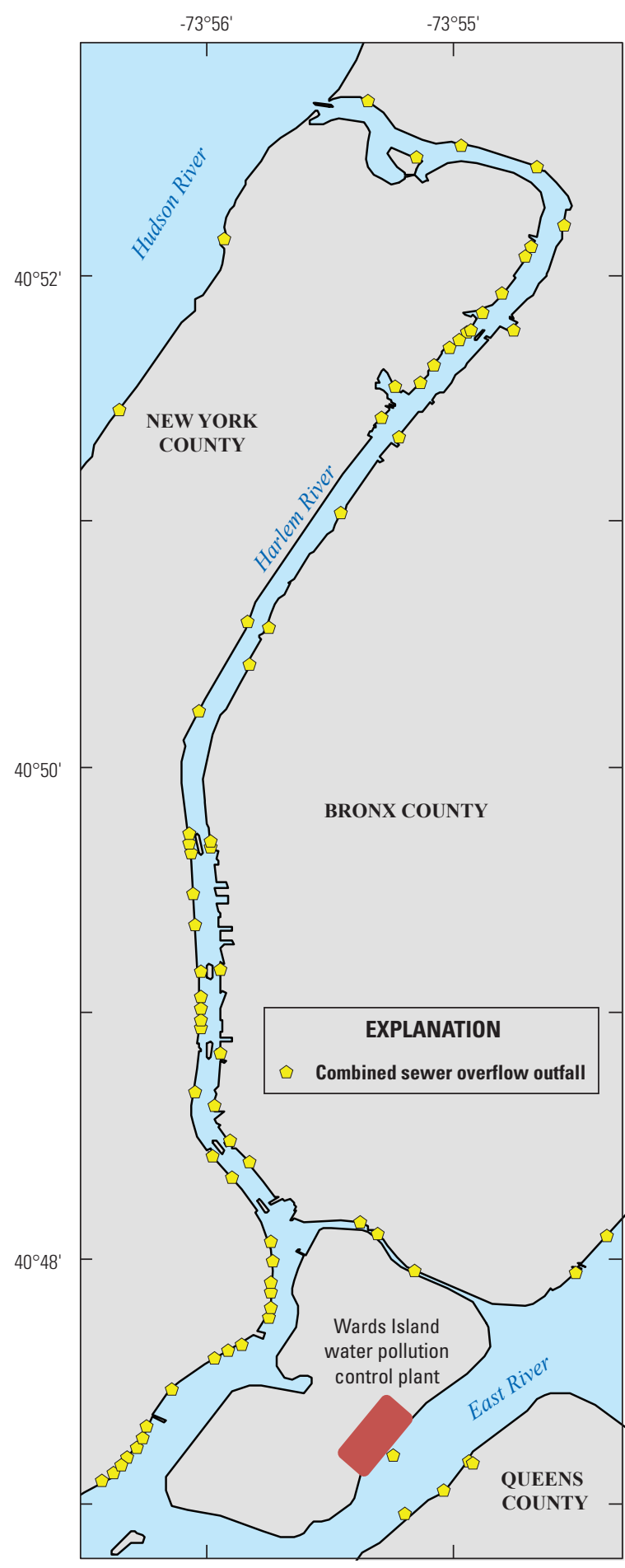

Base from digital data NOAA's Medium Resolution 1:70,000 scale Digital Vector Shoreline Lambert Conformal Conic Projection North American Datum of 1983 (NAD83)

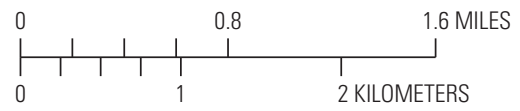

Figure 2. The Harlem River, New York, and locations of combined sewer overflow outfalls and the Wards Island water pollution control plant on the East River. 
(fig. 2) is also considered a point source of pollution. Alternatively, CSOs and WPCPs that discharge to other waterways in the region can be considered nonpoint sources to the Harlem River because of the mixing and tidal movement that transport contaminants to the Harlem River.

Nonpoint sources of pollutants also include stormwater runoff from roadways and other surfaces that flow directly into the river, precipitation, and waters from the Hudson River, Long Island Sound, and Atlantic Ocean (fig. 1). Diffuse pollution along the Hudson River and marine influences from the Atlantic Ocean and Long Island Sound influence properties such as salinity and nutrient (nitrogen and phosphorus) concentrations. Contributions from the Hudson River during a receding or ebb tide also include suspended sediments, which can transport pollutants such as organic contaminants (for example, pesticides) and metals sorbed to solid particles. On the incoming tide (flood tide), waters from WPCPs and CSOs move up the Harlem River.

Some contaminants dissolved in the water column ultimately become incorporated into the bed sediment through the deposition of suspended solids, to which many compounds tend to sorb. In addition, contaminated organic matter is released from wastewater treatment plants and CSOs as suspended solids, which can settle to the bottom. Depending on the frequency and intensity of release from a point or nonpoint source, contaminants become buried over time, forming a layer of potentially harmful deposits. Sediment in the Harlem River, as with the rest of the Harbor, has been negatively affected by centuries of industrial and transportation discharge. Good sediment quality is important to the health of shellfish, aquatic plants, and other organisms that live on the riverbed and seafloor. Sediment contaminated with heavy metals, toxic chemicals, and other compounds may harm or kill these organisms. Moreover, these pollutants can be transported up the food chain, leading to bioaccumulation in fish that may be consumed by humans.

The NYSDEC designates the Harlem River as a Class I (impaired) water body appropriate for secondary contact only (boating and fishing are permitted, swimming is not recommended); therefore, it is advised that certain shellfish and finfish caught in the Harlem River should not be consumed (New York State Department of Health, 2014). Contributing to these advisories are the effects of stormwater runoff, occasional discharges of CSO, and contaminated sediment of the Harlem River, which has been shown to contain polychlorinated biphenyls (PCBs), heavy metals, and other toxic organic pollutants (Mueller and Estabrooks, 2006). For this reason, the Harlem River has been continuously listed on the NYSDEC 303(d) "List of Impaired Waterways" (New York State Department of Environmental Conservation, 2014a). The presence of floatables, or litter, present in the river is also listed as a water-quality concern because it not only takes away from the aesthetics of the river but also can harm wildlife and contaminate the water column as residues (for example, soap from detergent bottles) move from the litter to water. In all likelihood, the Harlem River will remain in Class I status if CSO discharges continue to be a potential source of sewage and legacy contamination within the sediment remains a problem (New York State Department of the Environmental Conservation, 1999).

One of the first steps toward improving the water and sediment quality in the Harlem River is to identify the sources of pollutants and estimate their loads on the basis of land use, area, runoff, and other factors. A total maximum daily load (TMDL) study is commonly used to compile available data and set criteria for loading to waterways and is typically created for waters that have been designated as chronically impaired. In estuarine settings, TMDLs for nitrogen and phosphorus are often developed because minor changes in the loading of these nutrients can result in large algal blooms and ultimately deteriorate water quality. Applicable TMDLs that include the Harlem River have been developed for select heavy metals in 1994 and nutrients in 2000. Other indicators of poor water quality that may benefit from the development of a TMDL for the Harlem River include pathogens and suspended solids, both of which can be tied to wastewater infrastructure. After sources of these contributors to poor water quality have been identified, steps can be taken to reduce loading(s) into and upstream of the affected waterway or watershed (New York-New Jersey Harbor and Estuary Program, 2012).

\section{Purpose and Scope}

This report documents the relevant water-quality data compiled and evaluated for trends and highlights additional actions that could be implemented to help fill any gaps in existing data. Water-quality data the between 1945 and 2012 were evaluated to assess the variability and trends in parameters related to ecological health. Sediment-quality data were also evaluated to both emphasize the paucity of studies conducted on the Harlem River bed sediment and compare concentrations of metals toxic to marine life to concentrations in the entire Harbor.

\section{Water- and Sediment-Quality Data From the Harlem River}

The most comprehensive set of water-quality data for the Harbor has been generated through data-collection efforts by the NYCDEP and includes the five primary sampling locations along the Harlem River (fig. 1). Records of waterquality data along the Harlem River date back to 1914 for dissolved oxygen, temperature, and salinity. Throughout the years, the NYCDEP has added parameters to its list of analytes to provide more information for understanding the ecological health of the waters. These data can be used for modeling purposes, such as determining a correlation between precipitation, fecal indicator bacteria concentrations, and 
parameters such as dissolved oxygen and total suspended solids, which then can be used to predict when water quality will not meet criteria for human contact. These data also serve as a baseline used to track changes in water quality following improvements to the New York City wastewater infrastructure. (For example, there has been improvement in water quality since the 1970s when the CWA was implemented.) This trend has been documented in the annual Harbor water-quality survey reports (New York City Department of Environmental Protection, 2007) and indicates the effectiveness of infrastructure improvements to increase the capacity of the New York City WPCPs, thereby increasing the precipitation threshold for a CSO event.

The Hudson River Environmental Conditions Observation System (HRECOS) and the Stevens Institute of Technology use real-time monitoring data collected by the HRECOS and other agencies and organizations to model real-time changes in parameters such as salinity and flow in the Harbor, including a station in the Harlem River (Stevens Institute of Technology, 2014).

The Interstate Environmental Commission archive contains reports dating back to its inception in the 1930s for the Harbor and includes information on the status of New York City water and sewerage throughout the years before infrastructure changes, including CSO outfalls along the Harlem River.

In 2012, the NYCDEP began installing real-time monitoring stations around the Harbor to complement the harbor survey sampling effort. (Although at present [2016], no sites have been selected in the Harlem River.) Real-time modeling of the tidal cycle and basic water-quality parameters such as salinity, $\mathrm{pH}$, dissolved oxygen, turbidity, chlorophyll can be very useful for understanding the dynamic changes in the region. Research conducted by the USGS and other organizations has allowed for basic parameters such as these to serve as proxies of other water-quality problems, such as bacteria and nutrient transport. These data may be used to create models that can better predict CSO events and the extent of their effect when coupled with National Weather Service (NWS) precipitation data.

Bed-sediment-quality data also exist for the Harlem River, although these data have been collected less frequently than water-quality data. Studies and monitoring programs, such as the EPA Regional Environmental Monitoring Assessment Program (REMAP), have probed the benthic environment of New York and New Jersey to quantify the extent of contamination from centuries of urbanization (Adams and Benyi, 2003). Samples of sediment collected can be highly variable within a water body, however, depending on sampling location, depth, and proximity to current or past contamination sources. The paucity of data makes it difficult to understand changes in the sediment quality over time.

The Harlem River water- and sediment-quality data, along with the Central Park (New York, N.Y.) precipitation data, presented in this report are available in appendix 1, tables 1-1 to $1-7$ or by request of the respective collecting agency. The NYCDEP has water-quality data collected from the Harbor (including the Harlem River) dating back to 2008 from their Web site (http://www.nyc.gov/html/dep/ html/harborwater/harbor_water_sampling_results.shtml) and are planning to release all historical data in the near future. Groundwater and surface-water data collected by the USGS are available through the National Water Information System (NWIS) Web site (U.S. Geological Survey, 2014). Additional Harlem River data are available by accessing the links provided in table 1.

\section{Water-Quality Parameters of Ecological Importance}

The state of the Harlem River not only affects public recreation, but the health of the ecosystem as well. The health of the ecosystem can be assessed in part by using a combination of data, including nutrient levels, primary productivity, and water clarity. These factors can be used to define a trophic state index (TSI), which is used to gage the productivity level (including algae, fish, and shellfish) of a water body (U.S. Environmental Protection Agency, [2013]). Primary and secondary symptoms are also associated with the trophic levels (such as dissolved oxygen concentrations, persistence of harmful algal blooms, and the abundance of submarine aquatic vegetation), which are used as a qualitative measure to assign a grade to the water body such as the Harlem River (Bricker and others, 2003). (Note that in Bricker and others, 2003, the Harlem River is considered part of the Hudson River-Raritan Bay estuary.)

NYCDEP data collected over the past 65 years specific to the Harlem River have been summarized and presented in this report. The data show changes in water quality and the importance of continued monitoring to assess water-quality conditions (table 1). Of the five sampling locations along the Harlem River (H1 through H5, fig. 1), only H3 has continuous data collected after 2000. This site is still routinely sampled by the NYCDEP, although sporadic data exist after 2000 from periodic sampling efforts at the other sites. As a result, more than 90 percent of the data from 2000-12 in the following figures are from $\mathrm{H} 3$ exclusively. To ensure the comparison of the five sites relative to $\mathrm{H} 3$ was appropriate, data from each sampling location were plotted individually within the timeframes where data existed for all sites; data proved similar and were thus combined for this analysis. Where possible, water-quality standards and thresholds for local waterways are shown at the most relevant regional levels available for comparison (New York State Department of Environmental Conservation, 1999).

Although year-round data are generally available, only data from June through September (summer season) are shown. This was done because these months are typically the most active for water recreation and because of the greater frequency of sample collection by the NYCDEP during these months relative to others. Limited data are 
available from the winter months before the 1980s. Data were grouped into 5-year intervals to provide a summary of water-quality conditions.

The following data were obtained from the NYCDEP (K. Alamarie and B. Ranheim, Department of Environmental Protection Bureau of Wastewater Treatment, written commun. 2011) and were not collected or analyzed by the USGS. Box plots are used to graphically summarize the statistical range of concentrations measured in the Harlem River. Box plots can often be more useful than a single average or sum because they allow for extreme events (for example, high bacteria concentrations following an unusually high rain fall) to be represented. Specific data used to generate all boxplots shown herein except for fecal coliform are presented in table 1-8.

\section{Dissolved Oxygen}

One of the most important constituents of water quality is dissolved oxygen. The ecological health of an aquatic system depends mostly on the amount of oxygen in the water because aquatic fauna require oxygen to survive. As a result, dissolved oxygen is a secondary trophic indicator, where waters having low concentrations of dissolved oxygen are generally associated with eutrophic conditions and may also be rich in nutrients that promote a very high rate of primary productivity. Factors contributing to low concentrations of dissolved oxygen include high levels of bacteria that degrade organic matter and the decomposition of algae following a die-off of an algal bloom. Water-quality concerns attributed to increased algae production are discussed in the "TSI Indicators" section.

Concentrations of dissolved oxygen near the surface were chronically low throughout the mid-1900s (fig. 3). Following passage of the CWA in 1972, the median surface dissolvedoxygen concentrations in the Harlem River were found to have increased significantly by 1980 (statistically different at the alpha $=0.05$ level), exceeding the NYSDEC Class I water-quality threshold of 4 milligrams per liter (mg/L; fig. 3). Since the late 1990s, median dissolved-oxygen concentrations have remained above $5 \mathrm{mg} / \mathrm{L}$. These improvements are largely attributed to improvements in the wastewater infrastructure in and around the Harbor (New York City Department of Environmental Protection, [2010]).

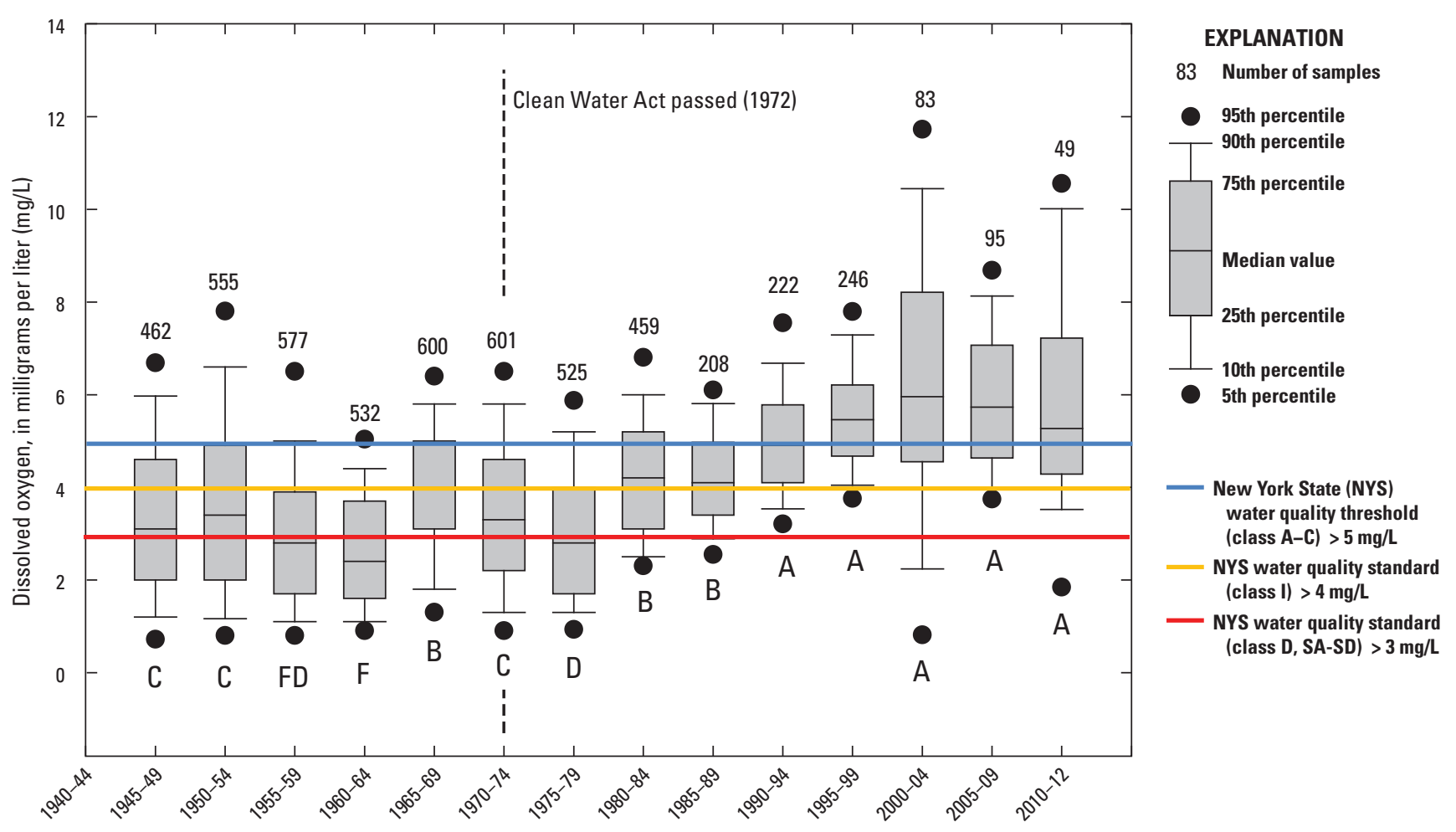

5-year seasonal data (June-September)

Figure 3. Dissolved oxygen concentrations in the Harlem River, New York, from June through September, depicted in 5-year intervals: 1945-99 (sites H1-H5), 2000 (sites H1-H3), 2001-12 (site H3). Data within each 5-year interval were compared to data within the other intervals using the Tukey test. Differing letters beneath the boxplots indicate median concentrations are significantly different at the alpha $=0.05$ level. 
Data from the last decade indicate that more than 75 percent of the samples collected have dissolved oxygen concentrations above the NYSDEC threshold of $3 \mathrm{mg} / \mathrm{L}$ required for sustaining fish populations. When concentrations of dissolved oxygen drop below $3 \mathrm{mg} / \mathrm{L}$, fish will either leave the area or die of hypoxia. In addition to the acute waterquality standard, Class I designation requires dissolved oxygen concentrations to be at or above $4 \mathrm{mg} / \mathrm{L}$ at all times. This requirement is not always met in samples collected in the river despite the improved water quality (fig. 3).

\section{Fecal Indicator Bacteria}

The concentration of fecal indicator bacteria is an indicator of potentially harmful bacterial pathogens in the water (although most species of indicator bacteria are not necessarily pathogenic; U.S. Environmental Protection Agency, 2012a). The main contributors to pathogenic bacteria in water include human waste in CSO discharge during a large precipitation event (or other CSO discharges), but can also include stormwater runoff in areas inhabited by wildlife. Prior to WPCP modernization, these treatment facilities were also a source of bacteria, because sewage was only partially treated prior to discharge.

\section{Fecal Coliform}

Fecal coliform concentrations are measured by counting the number of colonies in a culture following the incubation of a filtered sample of water and extrapolating back to the sample collected. Typically, the amount of water collected is normalized; thus, the concentrations of fecal coliform bacteria are reported as colonies per 100 milliliters $(\mathrm{mL})$. The current guideline for safe primary (Class A-D) contact with the water is a monthly geometric average of 200 colonies per $100 \mathrm{~mL}$, as set by the NYSDEC. Because the Harlem River has been designated as a Class I water body, the threshold is 2,000 colonies per $100 \mathrm{~mL}$ (monthly geometric average) to maintain safe, noncontact recreational use for fishing and boating. Summarized data used to generate figure 4 are presented in table $1-8$.

More than 90 percent of the fecal coliform bacteria colony counts in samples throughout the 1970s were above the 2,000 colonies per $100 \mathrm{~mL}$ NYSDEC threshold for Class I (fig. 4). Since the passage of the CWA in the 1970s, upgrades to WPCP have led to continued decreases in the number of CSO events that typically contribute to high levels of pathogens being introduced.

\section{Enterococcus}

Enterococcus is another class of potentially harmful bacteria in waterways affected by human and (or) animal waste. Relative to fecal coliform bacteria, the Enterococcus class has recently been proposed by the EPA as a better indicator for pathogenic bacteria because of its greater tolerance for higher salinity (that is, seawater), and thus Enterococcus is monitored in estuarine systems in conjunction with fecal coliform bacteria (Byappanahalli and others, 2013). Although freshwater inputs from the Hudson River may carry substantial concentrations of fecal coliform bacteria, the signal could be diminished as it is mixed with seawater introduced by way of the East River, whereas Enterococcus is more resilient to saline environments and may better indicate waters with harmful pathogens derived from wastewater discharge and stormwater runoff.

The NYCDEP has been testing for Enterococcus (along with fecal coliform bacteria) since 2001 at site H3 (fig. 5). Similar to criteria set for fecal coliform bacteria, a monthly geometric average of 35 colonies per $100 \mathrm{~mL}$ should not be exceeded for primary contact use. Unlike with fecal coliform bacteria, any given sample with Enterococcus concentrations exceeding 104 colonies per $\mathrm{mL}$ will trigger beach closures and water-use advisories. There is good correlation between the median concentrations of fecal coliform bacteria (fig. 4) and Enterococcus (fig. 5) over the past decade, although a higher percentage of samples collected exceeded the "unacceptable" threshold for Enterococcus relative to that for fecal coliform bacteria. This slight disparity shows why using the multiple indicators of water quality is important for understanding such a dynamic system like the Harlem River, where salinity can range from 2 to 32 practical salinity units because of the rapid tidal exchange between the Atlantic Ocean and the Hudson River.

\section{TSI Indicators}

\section{Nutrients}

Inorganic forms of nitrogen (nitrate, nitrite, and ammonia) are an important chemical component of fresh and marine waters, and along with phosphorus, are nutrients for primary producers such as algae. Algae and aquatic plants provide food, oxygen, and shelter for fish when nitrogen levels are balanced in the system; however, too much nitrogen can cause algal blooms, creating a mat that prevents light from penetrating the surface. Although photosynthesis generates oxygen during the day, respiration processes at night can cause the dissolved oxygen concentration in water to drop substantially. Furthermore, after consuming all of the nutrients, the algae die and sink to the bottom, which typically results in anoxic conditions as bacteria degrade the large influx of organic matter.

Sources of nitrogen include runoff, wastewater discharge (both treated and untreated), agriculture, and wildlife. Most of the older WPCPs are not equipped to process nitrogen (such as ammonia, nitrate, and nitrite) that enters the plant. As a result, the effluent contains nitrogen in the same form (typically ammonia) and concentrations, and in the same form when released into the adjacent waters (New York City Department of Environmental Protection, [2013]). Recent advances in 


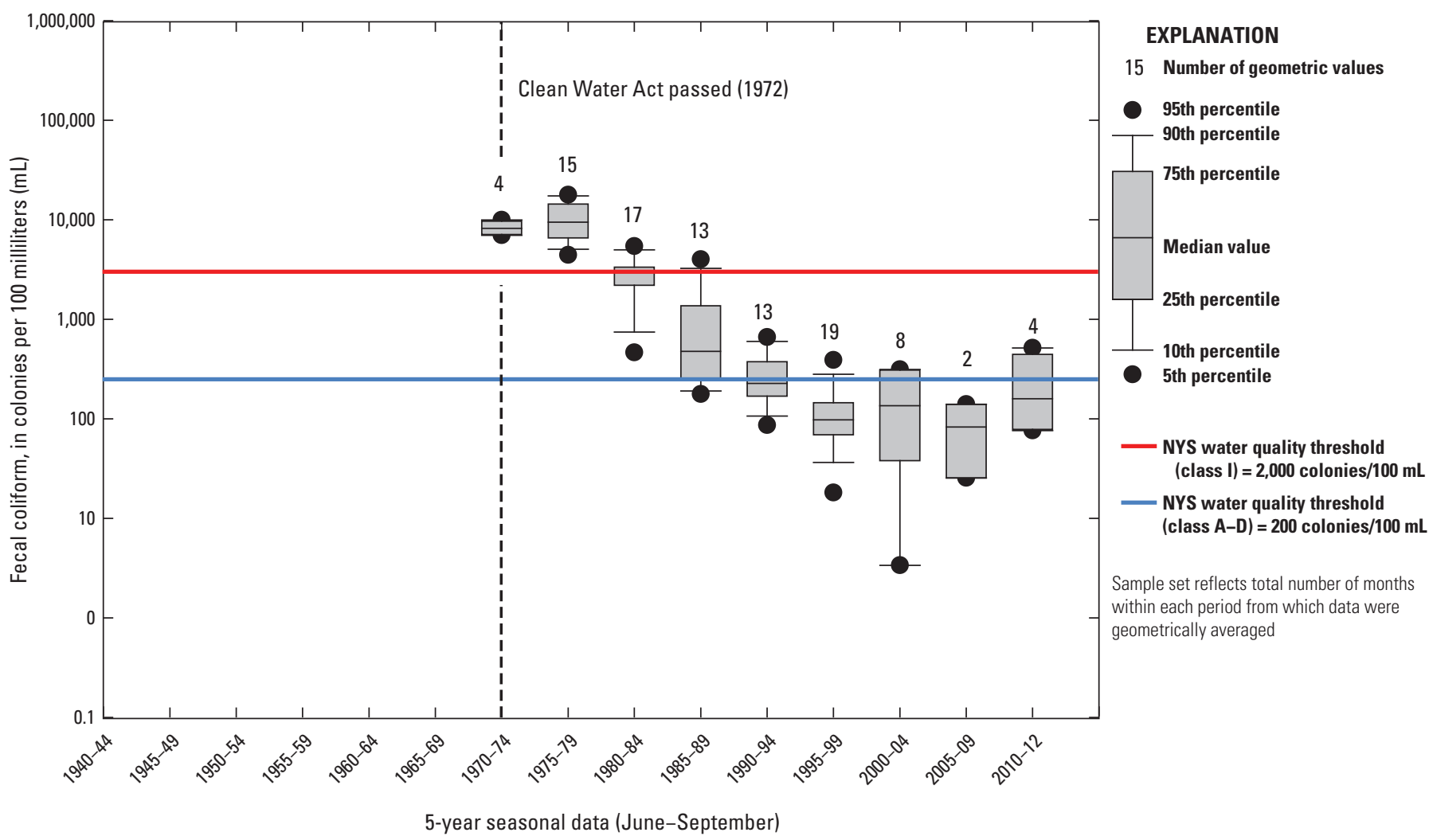

Figure 4. The geometric mean of fecal coliform concentrations in the Harlem River, New York, from June through September, depicted in 5-year intervals: 1974-99 (sites H1-H5), 2000 (sites H1-H3), 2000-12 (site H3). The geometric mean was calculated grouping the concentrations, for all sites, for each month from June through September. The smaller number of geometric means used from 2000 to 2012 reflects the removal of $\mathrm{H} 1, \mathrm{H} 2, \mathrm{H} 4$, and $\mathrm{H} 5$ from the sampling network.

wastewater treatment technology have enabled the New York City WPCPs to improve their processing of dissolved organic and inorganic nitrogen by converting it to nitrogen gas through modifying their existing infrastructure to include a denitrification step.

Analytical methods used by the NYCDEP detect nitrate and nitrite together and report the summed value in concentration as nitrogen (that is, "nitrate + nitrite in $\mathrm{mg} / \mathrm{L}$ as nitrogen") because nitrite is readily converted to nitrate in oxygenated waters. The range of nitrate + nitrite concentrations has not varied much (median values between 0.4 and $0.6 \mathrm{mg} / \mathrm{L}$ as nitrogen) in the Harlem River over the past 25 years (fig. 6). As of 2014, no formal New York State water-quality criteria exist for nutrients (phosphorus and nitrogen) in estuarine waters; however, the NYSDEC has been working with the EPA to develop them (U.S. Environmental Protection Agency, 2014c). Therefore, the EPA criterion for dissolved inorganic nitrogen (which also includes dissolved ammonia) was chosen as a water-quality reference, such that a concentration less than $0.1 \mathrm{mg} / \mathrm{L}$ as nitrogen would constitute good ecological health, and a concentration greater than
$0.5 \mathrm{mg} / \mathrm{L}$ as nitrogen would constitute poor ecological health (fig. 6; U.S. Environmental Protection Agency, 2012c). Of all the samples collected by the NYCDEP from the Harlem River since 1985, 36 percent had concentrations of nitrate + nitrite that were at or exceeded $0.5 \mathrm{mg} / \mathrm{L}$ as nitrogen.

Ammonia is another form of inorganic nitrogen that is typically associated with wastewater or agricultural runoff. Primary sources of ammonia in the environment include human and animal waste, fertilizer, and bacteria in anoxic sediment. Unlike concentrations of nitrate + nitrite in the Harlem River (fig. 6), ammonia concentrations at or above the upper 95th percentile have been steadily decreasing since the mid-1990s (fig. 7). This is probably a result of the improvements in the WPCPs in New York City and upstream along the Hudson River.

Of all the samples collected by the NYCDEP from the Harlem River since 1985, 13 percent had concentrations of ammonia that were at or exceeded the EPA criterion for poor ecological health of $0.5 \mathrm{mg} / \mathrm{L}$ dissolved inorganic nitrogen. When concentrations of ammonia and nitrate + nitrite were added on a per-sample basis to approximate dissolved 


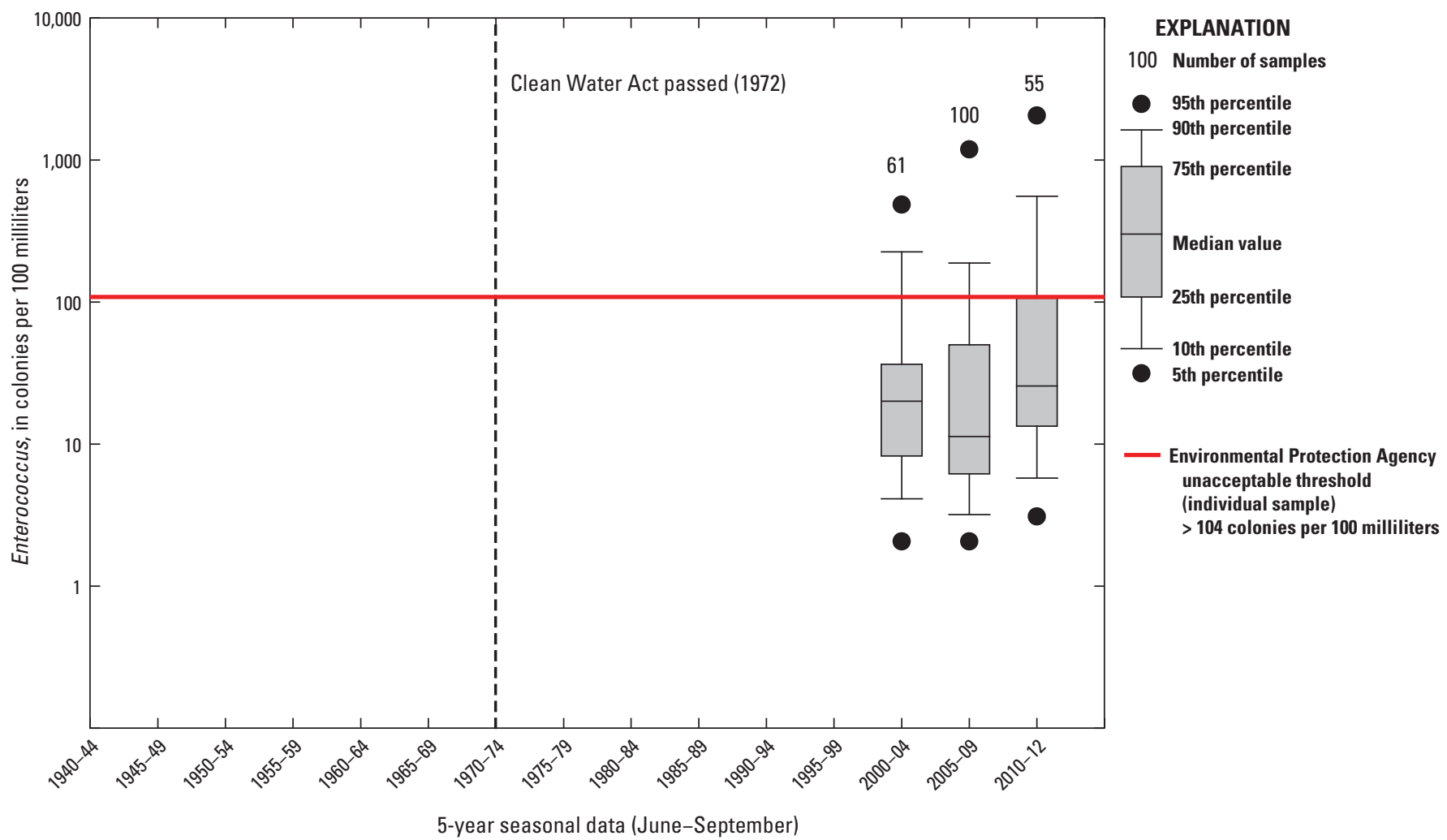

Figure 5. Enterococcus concentrations at site $\mathrm{H} 3$ in the Harlem River, New York, from June through September, depicted in 5-year intervals. As this is a relatively new method for assessing wastewater influence in marine waters, data are only available starting in early 2000s. The median Enterococcus concentration has been below the U.S. Environmental Protection Agency unacceptable levels in each of the 5-year intervals. However, there are still instances where high Enterococcus concentrations were detected (in at most 10 percent of detection per interval).

inorganic nitrogen concentration, 97 percent of samples collected from the Harlem River since 1985 exceeded the $0.5 \mathrm{mg} / \mathrm{L}$ as nitrogen EPA criterion for poor ecological health (data not shown).

Phosphorus is another important nutrient required for a healthy ecosystem. Compared to nitrogen, a relatively small amount of phosphorus is needed for algae formation (Redfield, 1958), and too much can cause eutrophication. As with inorganic forms of nitrogen, sources of inorganic phosphate (orthophosphate) to the Harlem River include agricultural runoff that can be transported from the Hudson River or the Long Island Sound and wastewater that is directly discharged to the Harlem River and surrounding waters. Orthophosphate refers to a single phosphate molecule, and unlike nitrite and nitrate, it can form complexes readily with other dissolved constituents (such as metal ions), sorb to particles, and be removed from the dissolved phase depending on the water chemistry.
The concentration of dissolved orthophosphate in seawater can be relatively consistent and low (typically less than $0.01 \mathrm{mg} / \mathrm{L}$ as phosphorus), and because the tidal exchange between the Atlantic Ocean and the Hudson River occurs twice daily, the range of phosphate is narrow and does not change much from year to year along the Harlem River (fig. 8). As with nitrogen, the EPA criteria for dissolved inorganic phosphorus were used. A concentration of dissolved inorganic phosphate less than $0.01 \mathrm{mg} / \mathrm{L}$ would constitute good ecological health, whereas a concentration greater than $0.05 \mathrm{mg} / \mathrm{L}$ would constitute poor ecological health. Ninety percent of samples collected from the Harlem River from 1985 to 2008 exceeded the $0.05 \mathrm{mg} / \mathrm{L}$ as phosphorus EPA criterion for poor ecological health.

Briefly between 2009 and 2012, orthophosphate was removed from the NYCDEP list of constituents in favor of total phosphorus, which includes organic phosphorus that can be cycled into forms of phosphate that may be utilized by 


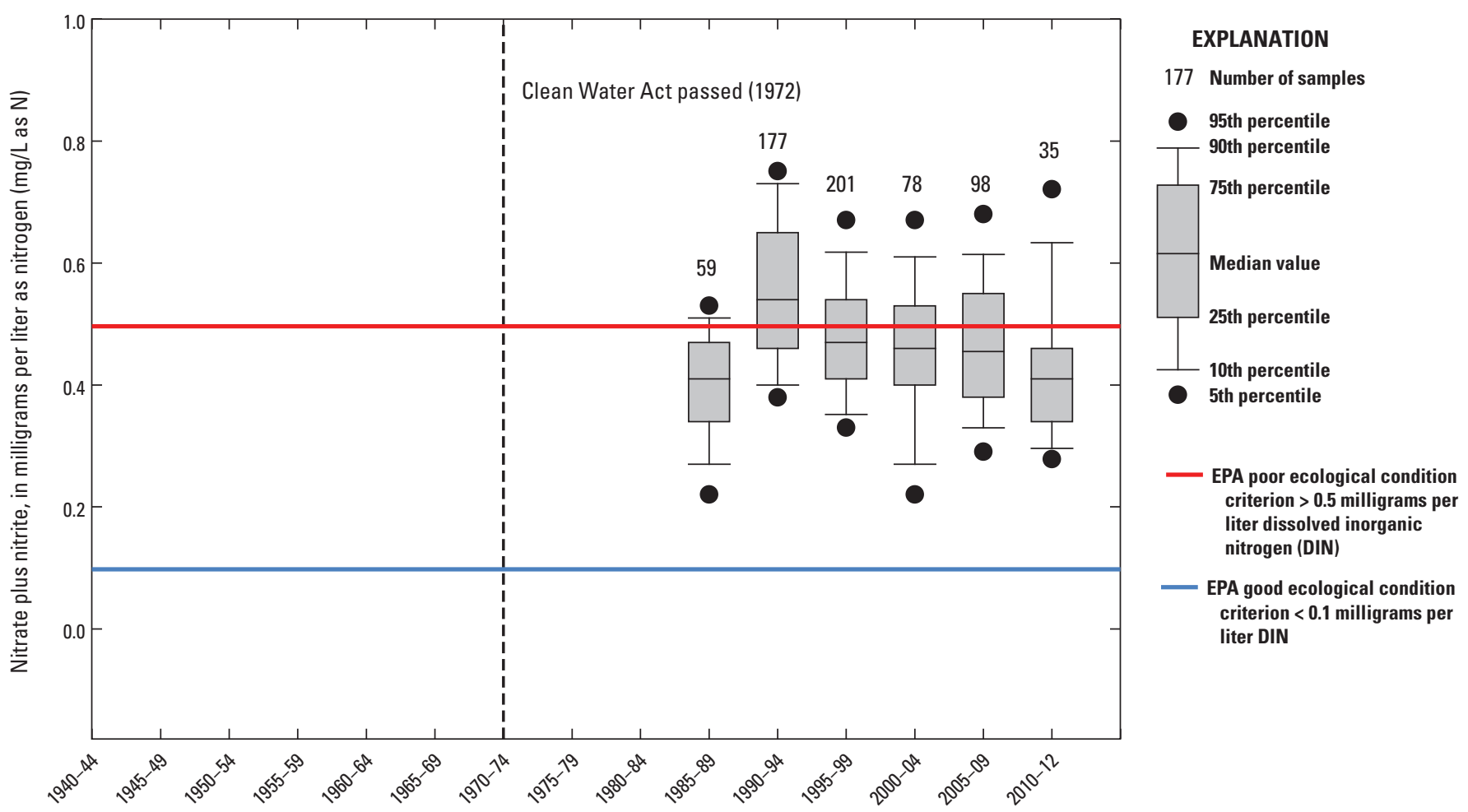

5-year seasonal data (June-September)

Figure 6. Nitrate and nitrite concentrations along the Harlem River, New York, from June through September, depicted in 5-year intervals: 1987-99 (sites H1-H5), 2000-12 (site H3). The median nitrate and nitrite concentrations have remained near the U.S. Environmental Protection Agency (EPA) fair ecological condition criterion for total dissolved nitrogen, which includes other forms of organic and inorganic nitrogen species. Thus, it is likely that median concentrations of total dissolved nitrogen in the Harlem River at the time samples were collected are above this criterion.

aquatic flora. Orthophosphate has since been added back to the analyses along with total phosphorus.

\section{Chlorophyll a}

Chlorophyll is a class of pigments that allows plants to use sunlight to generate sugar for energy through photosynthesis. In estuarine waters, such as the Harlem River, the detection of chlorophyll $a$ (the most prevalent type of chlorophyll) is generally attributed to the presence of algae. Algae are an important part of the aquatic food chain because they provide food to larger organisms and generate oxygen during photosynthesis, which increases dissolved oxygen concentration in the water. Too much algae can actually result in a decrease in water quality, however, because dissolved oxygen concentration can drop considerably when large mats of algae die and sink to the bottom.

The diurnal changes in tide can also result in the presence of different types of algae in the Harlem River depending on the source of water, the season, salinity, and water temperature. Chlorophyll $a$ concentrations from 1985 to 2012 have generally remained at or below the EPA criterion for good ecological health of 5 micrograms per liter ( $\mu \mathrm{g} / \mathrm{L}$; fig. 9). The highest concentrations of chlorophyll $a$ were observed during the latter half of the 1990s, which are the only years in which the median value of chlorophyll $a$ reached $5 \mu \mathrm{g} / \mathrm{L}$. Some samples had chlorophyll $a$ concentrations above the EPA criterion for poor ecological health of $20 \mu \mathrm{g} / \mathrm{L}$, although there were no indications for the cause of these higher values when comparing other parameters corresponding to these samples.

\section{Water Clarity}

Water clarity is a property of water that is affected by various factors - including concentrations of soil particles, flocculants, dissolved organics, and algae - that ultimately govern the amount of light that can pass through the water column. Dissolved organic matter and humic substances can darken the water but are not particles that can be filtered out of a sample. In contrast, suspended solids are particles in the 


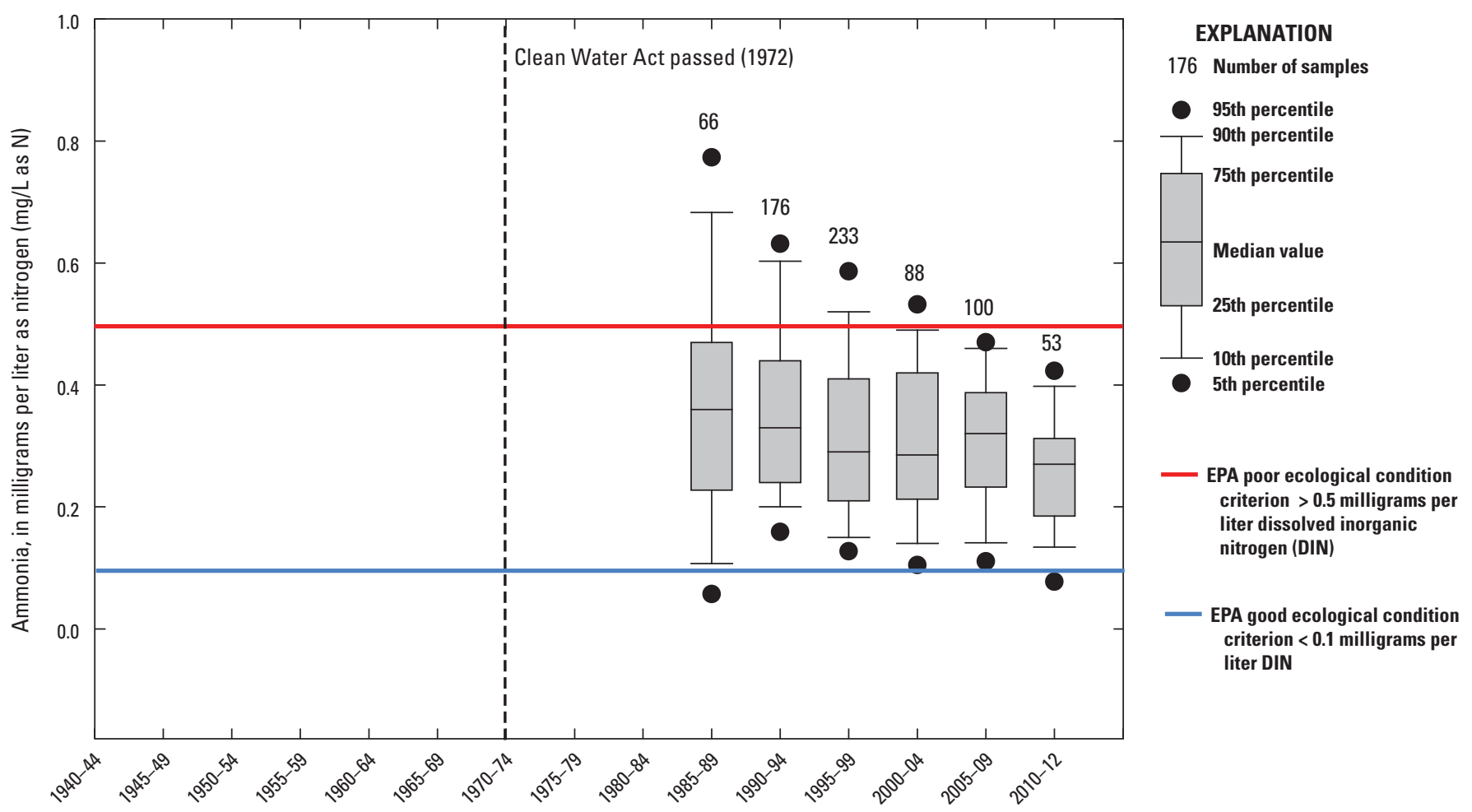

5-year seasonal data (June-September)

Figure 7. Ammonia concentrations along the Harlem River, New York, from June through September, depicted in 5-year intervals: 1986-99 (sites H1-H5), 2000-12 (site H3). The median ammonia concentrations have remained below the U.S. Environmental Protection Agency (EPA) fair ecological condition criterion for total dissolved nitrogen, which includes other forms of organic and inorganic nitrogen species. It is likely that median concentrations of total dissolved nitrogen (which includes nitrate and nitrite; fig. 6) in the Harlem River at the time samples were collected are above this criterion.

water column that can include sediments, soil, algae, and organic matter. The measure of suspended particle interference with light penetration is known as turbidity.

The amount of suspended solids in a water sample is determined by filtering the sample and weighing what remains. Particles that remain suspended are typically small and move through the water column as a dense plume or are dispersed over a large area. Failure of a WPCP, CSO discharge, or large storms that stir up bed sediment can all increase the concentration of suspended solids substantially. An increase in suspended solids, decreases the amount of light can penetrate the water column, which in turn decreases primary productivity (such as that of beneficial benthic plants).

Suspended solids can be used as a proxy for other contaminants that are typically associated with a site or watershed. For example, tracking sediment transport from a known source of agricultural runoff containing dissolved pesticides known to adsorb to particles can inform the exposure and concentrations of pesticides in the sediment deposited downstream. Proxy analytes are an efficient monitoring tool, because once a link between concentrations of a contaminant and suspended solids is established, collecting samples for suspended solids analyses and monitoring turbidity downstream of a source can be done more frequently and cheaply than a full chemical analysis, yet still give a sense of the fate and transport of the contaminant.

In the Harlem River, sources of suspended solids include discharge from CSOs, runoff from roadways and infrastructure, shoreline redevelopment, and upwelling from the riverbed during high flow and (or) mixing. Concentrations of total suspended solids in the Harlem River have trended downward slightly since the 1990s and appear to have leveled off within the 95th percentile at lower concentrations between 2005 and 2012 (fig. 10). This decrease in suspended solids concentration can mostly be attributed to improvements in wastewater treatment in New York City (New York City Department of Environmental Protection, [2010]) and in towns along the Hudson River (Hetling and others, 2003). 


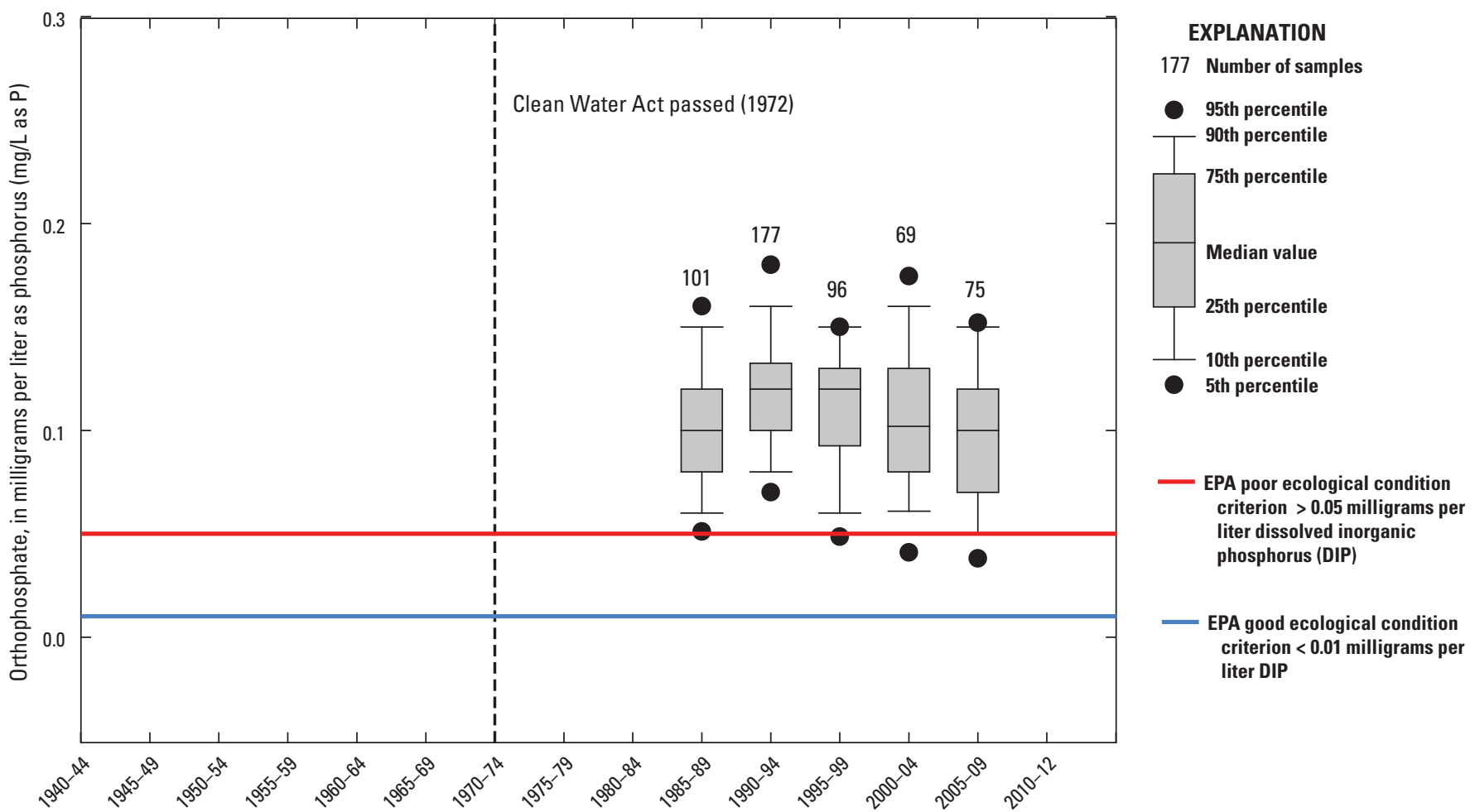

5-year seasonal data (June-September)

Figure 8. Orthophosphate concentrations along the Harlem River, New York, from June through September, depicted in 5-year intervals; 1986-96 and 1998-99 (sites H1-H5), 2000-2008 (site H3). Median concentrations of orthophosphate remained around $0.1 \mathrm{mg} / \mathrm{L}$ as phosphorus over the 25 years it was included in the suite of analyses.

Wastewater infrastructure improvements, along with a number of other factors (such as the invasion of zebra mussels in the Hudson River that reduce the plankton population to turbid waters; Caraco and others, 1997), have contributed to greater water clarity in the Harbor over the past two decades.

\section{Sediment Quality}

The EPA collected bed sediment samples at one location in the Harlem River during the summer of 2003 for analysis of heavy metals, polycyclic aromatic hydrocarbons (PAHs), pesticides, and a number of PCB congeners. This sample was collected as part of the REMAP in the New York-New Jersey Harbor (fig. 1; U.S. Environmental Protection Agency, 2012b, site UH361). Results from this single sampling event reveal that, compared to the median concentrations of metals having known ecological toxicities in the sediment collected from the New York-New Jersey Harbor during the summer of 2003, the sediment quality in the Harlem River had lower concentrations of mercury, lead, copper, and nickel than the median concentrations of the sediment taken from the rest of the Harbor (fig. 11, tables 1-2 and 1-4). Concentrations of mercury, lead, copper, and nickel were all within the 10th to 25 th percentile range among all sediment collected in the New York-New Jersey Harbor.

The NYSDEC has collected and analyzed surficial bed sediment and sediment cores from water bodies throughout New York State since 1994, including six points along the Harlem River in 2000 (table 1-5). A list of contaminants of concern identified by the EPA and NYSDEC was compiled for the study and included select heavy metals, PCBs, pesticides, and PAHs (Mueller and Estabrooks, 2006). Toxic metals such as chromium, lead, and tin, identified by the NYSDEC in the Status and Trends Report for Freshwater and Marine Sediments study (New York State Department of Environmental Conservation, 2014b), were detected at concentrations greater than their respective sediment criteria considered safe for aquatic life by the NYSDEC. 


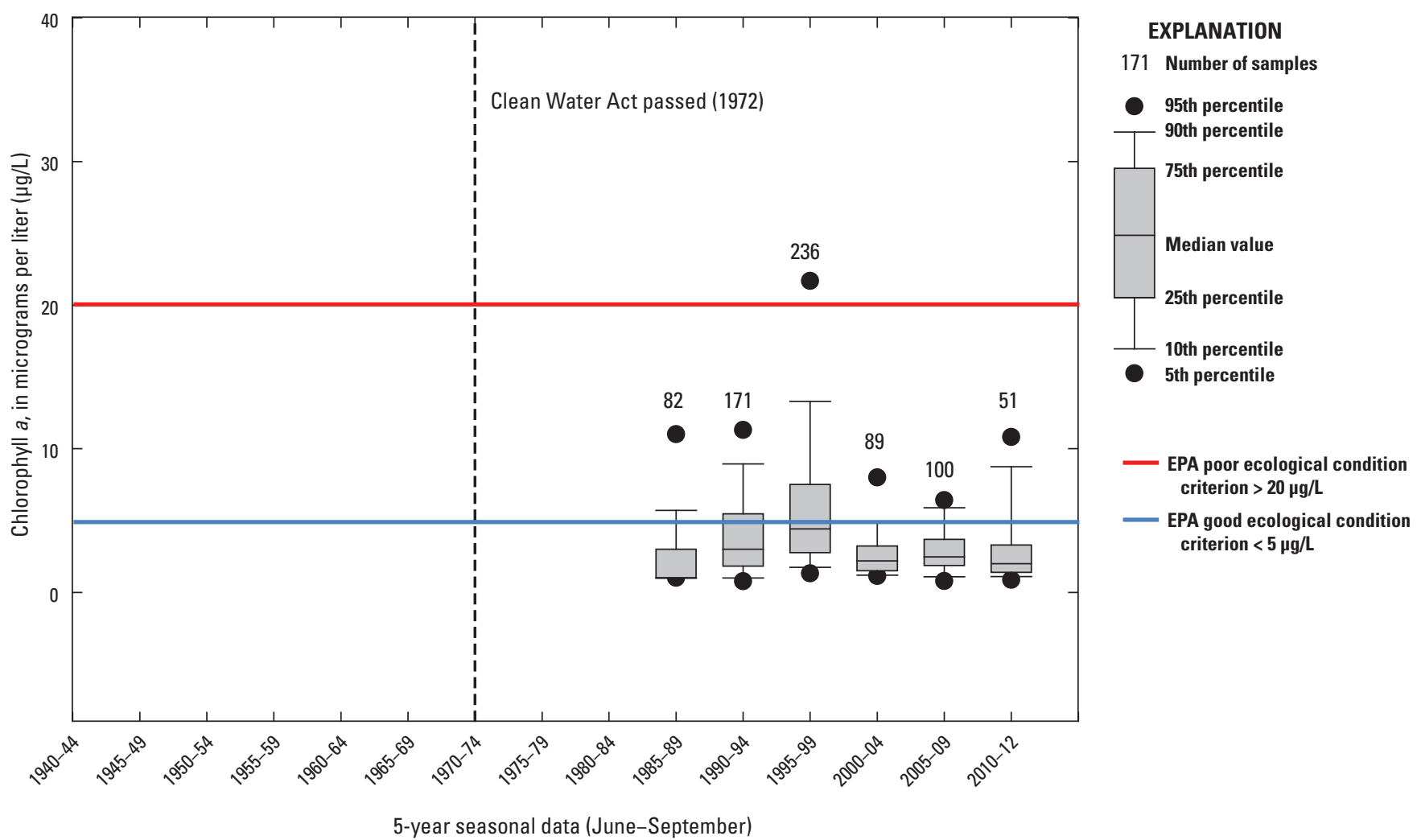

Figure 9. Chlorophyll a concentrations along the Harlem River, New York, from June through September, depicted in 5-year intervals: 1986-90 and 1992-99 (sites H1-H5), 2000 (sites H1-H3), 2001-12 (site H3). The median chlorophyll a concentrations have remained below the U.S. Environmental Protection Agency (EPA) fair ecological condition criterion over the 25-year period.

\section{Precipitation and Other Water-Quality Data}

Annual precipitation data have been compiled from the NWS Central Park weather station from 1945-2012 for the summer months (June to September) for consistency with water-quality data presented in this report (fig. 12). Although data presented in figure 12 dates back to 1945 to correspond to the early dissolved oxygen data, the complete period of record for this weather station is more than 100 years, dating back to the 1890s (table 1-7; http://water.weather.gov/precip/ download.php). A solid trend line in figure 12 represents the moving average to illustrate variability and a slight increasing trend in precipitation over the last 60 years. Precipitation is another variable to consider when evaluating water-quality data such as nitrogen concentrations and bacteria levels. Despite higher precipitation (on average), the water quality of the Harbor has been improving since the 1970s (see figs. 3 and 4) because of infrastructure improvements and better land-use practices.

In addition to sediment and surface-water samples from the Harlem River, the USGS has sampled groundwater from two bedrock wells (NY 250.1 in 2006; and NY 251.1 in 2006,
2008, and 2011) for more than 300 major ions, trace metals, and organic and inorganic compounds in Central Park. Results indicate concentrations of pesticides, wastewater-indicator compounds, and volatile organic compounds (VOCs) and semivolatile organic compounds (SVOCs) were all below the submicrogram-per-liter method reporting limits, whereas nutrient concentrations were in the low milligram per liter range for both wells (U.S. Geological Survey, 2014).

\section{Data Gaps}

It is difficult to gauge the overall health of a dynamic water body like the Harlem River without continuous monitoring. The effects of tidal changes, sudden and intense upland contributions, and precipitation-driven CSO events on the ecosystem may not be properly evaluated or may occur between the collection of discrete water samples. In such cases, the influence of significant events is not documented, leading to an incomplete assessment of the water quality. In fresh and estuarine waters, the trophic state can be estimated on the basis of nutrient concentrations (nitrogen and phosphorus), chlorophyll levels, transparency, and dissolved 


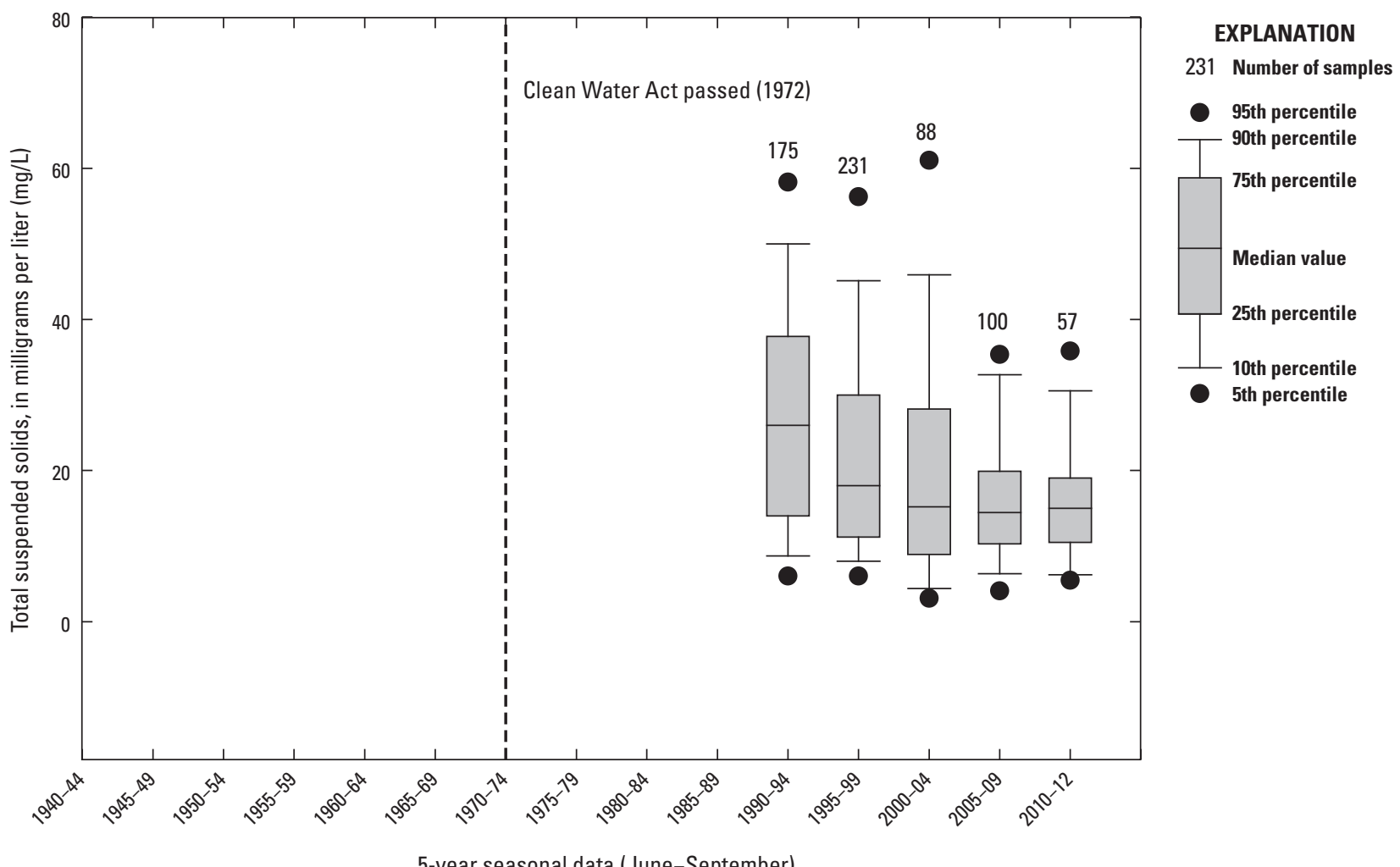

Figure 10. Total suspended solids concentrations along the Harlem River, New York, from June through September, depicted in 5-year intervals: 1991-99 (sites H1-H5), 2000 (sites H1 and H3), 2001-12 (site H3). The median suspended solids concentrations have been constant over the past 20 years, though the number of samples containing suspended solids in the 75 percentile and higher decreased significantly in the late 2000s.

oxygen concentrations; the same can be done in the Harlem River. Real-time monitoring of basic water-quality parameters along the Harlem River would allow for better interpretation of the weekly (or monthly in winter months) grab samples collected by the NYCDEP.

The NYCDEP has been working to implement a realtime data network throughout the Harbor that will help fill this need and may be useful in assessing historical data should a model be developed. Although the median concentrations of the water-quality parameters monitored in the Harlem River over the past 40 years indicate improving conditions, outliers in fecal coliform bacteria and dissolved oxygen data indicate that there are still times when water-quality in the river is poor. Recent advancements in water-quality sensor technology allow for the analysis of a number of basic parameters that can be evaluated continuously and over time to establish trends in physical parameters relative to the tidal cycle, WPCP and CSO discharges, the presence of pathogens, and precipitation; for example, changes in dissolved oxygen and turbidity can be assessed along with changes in salinity to determine contributions of particle loading from various sources such as the Hudson River, and WPCPs or CSOs. Turbidity is a commonly used measure that can also be used as a proxy for more complex parameters, such as particulate organic matter concentration and suspended sediment concentration, if source water has been previously defined. Understanding the trends in dissolved oxygen, pathogens, nutrients, and TSS loads through continuous monitoring and development of TMDLs can allow city, State, and Federal agencies to make critical changes to both wastewater and transportation infrastructure to help lessen the effects of discharges and runoff in the future.

There are also growing concerns that emerging contaminants (such as pesticides, personal care products, pharmaceuticals, and detergents), which have been detected in both treated and untreated wastewater, can persist in the water and sediment and adversely affect wildlife such as fish and birds. These emerging contaminants can be used to track wastewater effluent discharging from WPCP. Further study of the fate and transport of wastewater-derived chemicals in urban waters and sediment would be useful and could supplement future models that simulate the effects of wastewater infrastructure in the New York City region. 


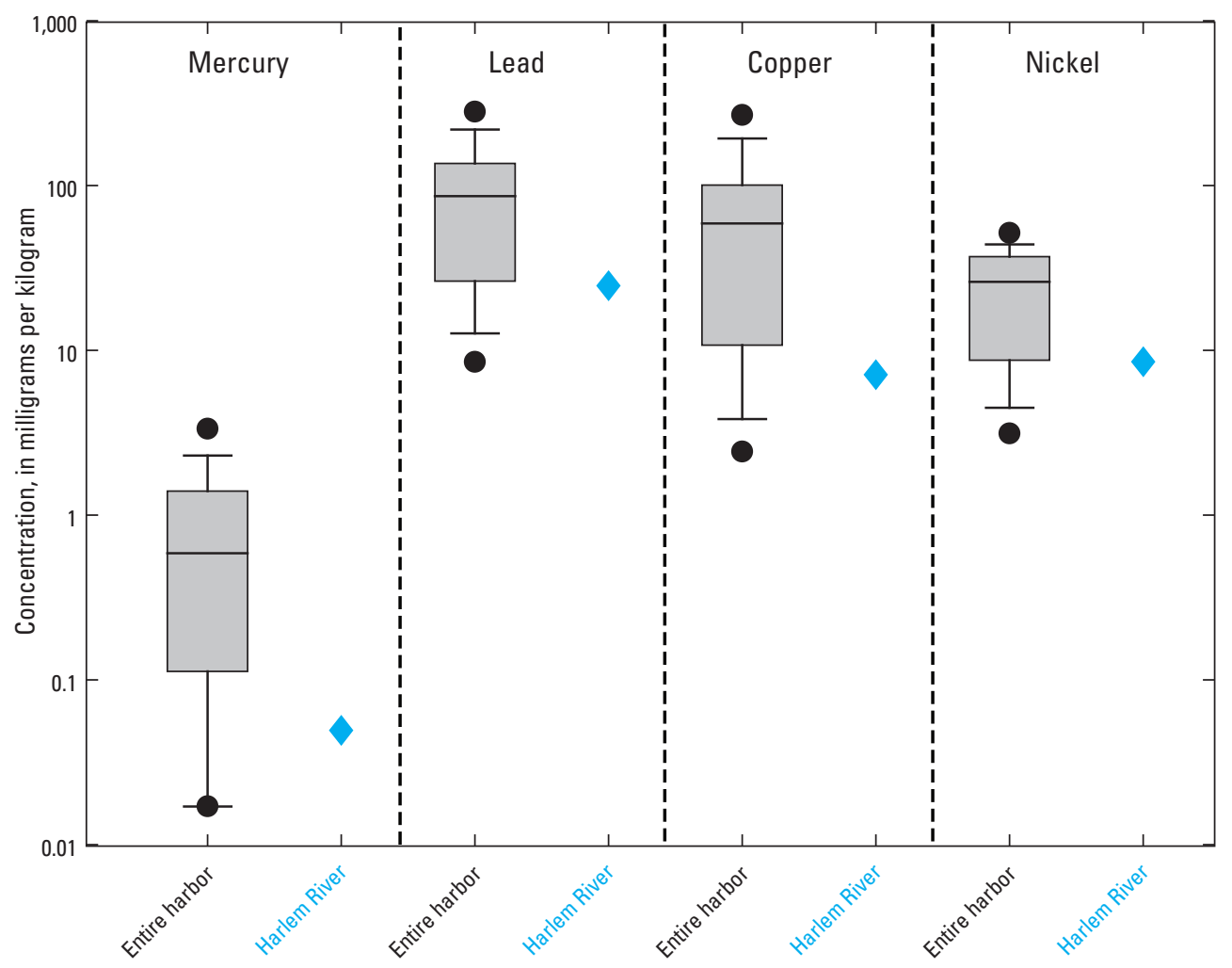

EXPLANATION

- 95th percentile 90th percentile

75th percentile

75 percentile

Median value

25th percentile

10th percentile

5th percentile

EPA REMAP site UH361

Figure 11. Select metals with known ecological toxicity detected in sediment samples taken from the Harlem River (U.S. Environmental Protection Agency [EPA] Regional Environmental Monitoring Assessment Program [REMAP] site UH361) relative to the New York-New Jersey Harbor in 2003. Concentrations of mercury, lead, copper, and nickel in the sediment sample collected from the Harlem River were all within the 10th to 25th percentile among all sediment collected in the Harbor. Each box plot represents data from all 112 sites in the New York-New Jersey Harbor (that is, the number of samples equals 112 for each metal).

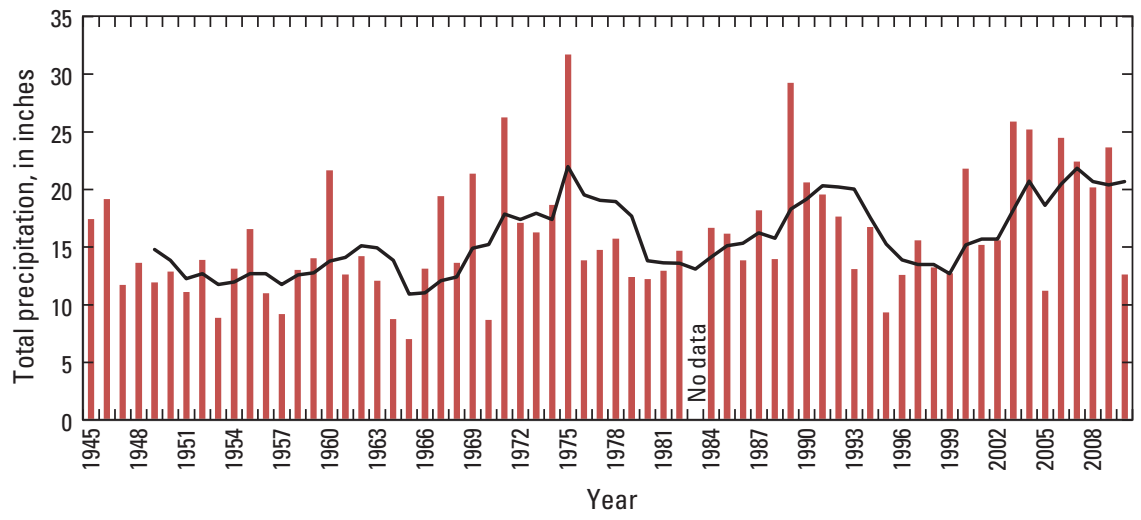

Figure 12. Precipitation totals for June through September in the years that waterquality data are presented in this report (National Weather Service Central Park weather station). The solid line represents a 5-year moving average that shows periods of oscillation and an overall upward trend. 


\section{Summary}

The U.S. Geological Survey (USGS) has compiled water-quality data relevant to the Harlem River, including data from the century-old monitoring program being conducted by the New York City Department of Environmental Protection (NYCDEP), to provide a resource for stakeholders and the community to make informed decisions about protecting this natural resource. Water quality in the Harlem River has improved since the early 1940s because of improvements in wastewater treatment in and around the city, spurred by the community's desire for cleaner waters and by Federal legislation. And although the improvements in water quality on a citywide basis are apparent from studying photos, literature, and water-quality trends since the 1940s, data indicate that there are still instances when waterquality standards set by the New York State Department of Environmental Conservation (NYSDEC) are not met, typically during intense or prolonged periods of precipitation when stormwater runoff causes the discharge of untreated sewage to the Harlem River (and throughout New York City). Yet there is clearly a positive trend in water quality, which ultimately improves the ecological health and aesthetics of the river.

Important environmental indicators, such as dissolved oxygen concentration, have steadily improved above NYSDEC and the U.S. Environmental Protection Agency (EPA) water-quality standards. Other core indicators of water quality are bacteria and suspended solids - both of which have also shown improvements during the past 20 yearsand nutrients. High levels of nitrogen and phosphorus, as well as fecal bacteria, are probably related to combined sewer overflow (CSO) events and to effluent from water pollution control plants (WPCPs), but such levels can also be linked to urban runoff and wildlife. The rapid, diurnal tidal exchange between the Hudson River and ocean water introduces the potential for these and other contaminants to be transported from upland and offshore sources. The continuation of programs such as the NYCDEP Harbor Survey provide essential data for making decisions related to wastewater treatment and the effect of both treated and untreated wastewater discharge to the environment. Advances in wastewater infrastructure to improve treatment and prevent CSO events are ongoing in New York City, with the ultimate goal of creating a healthier ecosystem for aquatic life and safe water for recreational use.

Bed sediment throughout the New York-New Jersey Harbor has been shown to contain a number of legacy contaminants (including polychlorinated biphenyls and heavy metals) that were used extensively in New York City over the years. In 2003, a study by the EPA Regional Environmental Monitoring Assessment Program found concentrations of mercury, lead, copper, and nickel in bed sediment to be lower at a Harlem River sampling location than at many of the other sampling locations within the Harbor. A new round of sediment sampling along the Harlem River would provide data critical for assessing the state of its benthic environment.
Community access along both shores of the Harlem River is limited to a much greater extent than it was prior to urbanization; moreover, water quality in the river is substantially affected by WPCP effluent and the multiple CSOs that discharge to the river. As a result, suggested use of the river is now limited by regulators. Continuous monitoring of physical parameters at publicly accessible points along the Harlem River would allow regulators to make informed decisions regarding public safety in real-time. Systematic collection of samples for laboratory analysis would be required to establish a correlation between water-quality parameters collected through continuous monitoring and conditions of the Harlem River. This information would also provide officials with the information needed to make informed decisions regarding the management of wastewatertreatment infrastructure. To that end, Federal agencies have joined with State and local municipalities and organizations to promote healthier urban waterways with the hope of educating the public about the need for a cleaner environment.

\section{Selected References}

Adams, D.A., and Benyi, Sandra, 2003, Sediment quality of the NY/NJ harbor system-A 5-year revisit: An investigation under the Regional Environmental Monitoring and Assessment Program (REMAP): U.S. Environmental Protection Agency EPA/902-R-03-002, 51 p.

Blumberg, A.F., Kahn, L.A., and St. John, J.P., 1999, Threedimensional hydrodynamic model of New York harbor region: Journal of Hydraulic Engineering, v. 125, no. 8, p. $799-816$.

Bricker, S.B., Ferreira, J.G., and Simas, T.C., 2003, An integrated methodology for assessment of estuarine trophic status: Ecological Modelling, v. 169, no. 1, p. 39-60.

Byappanahalli, M.N., Nevers, M.B., Korajkic, Asja, Staley, Z.R., and. Harwood, V.J., 2012, Enterococci in the environment: Microbiology and Molecular Biology Reviews, v. 76, no. 4, p. 685-706.

Caraco, N.F., Cole, J.J., Raymond, P.A., Strayer, D.L., Pace, M.L., Findlay, S.E.G., and Fischer, D.T., 1997, Zebra mussel invasion in a large, turbid river-Phytoplankton response to increased grazing: Ecology, v. 78, p. 588-602.

City University of New York, 2014, New York City Oasis map: City University of New York, accessed November 14, 2014, at http://www.oasisnyc.net/map.aspx.

Hetling, L.J., Stoddard, Andrew, Brosnan, T.M., Hammerman, D.A., and Norris, T.M., 2003, Effect of water quality management efforts on wastewater loadings during the past century: Water Environment Research, v. 75, p. 30-38. 
Metropolitan Transit Authority, 2012, Greening mass transit and metro regions-The final report of the blue ribbon commission on sustainability and the MTA: Metropolitan Transit Authority, State of New York, 89 p., accessed November 14, 2014, at http://web.mta.info/sustainability/ pdf/SustRptFinal.pdf.

Mueller, Sara, and Estabrooks, Frank, 2006, New York status and trends report for freshwater and marine sediments: Albany, N.Y., New York State Department of Environmental Conservation, $397 \mathrm{p}$.

New York City Department of Environmental Protection, 2007, New York harbor water quality survey: New York City Department of Environmental Protection Web page, accessed November 14, 2014, at http://www.nyc.gov/html/ dep/html/news/hwqs.shtml.

New York City Department of Environmental Protection, [2010], New York Harbor Survey Program — Celebrating 100 years - 1909-2009: New York City Department of Environmental Protection, 28 p., accessed April 4, 2013, at http://www.nyc.gov/html/dep/pdf/hwqs_centennial.pdf.

New York City Department of Environmental Protection, [2013], New York City's wastewater treatment system: New York City Department of Environmental Protection, 32 p., accessed April 4, 2013, at http://www.nyc.gov/html/dep/pdf/ wwsystem.pdf.

New York-New Jersey Harbor and Estuary Program, 2012, The state of the estuary 2012-Environmental health and trends of the New York-New Jersey Harbor Estuary: U.S. Environmental Protection Agency, $30 \mathrm{p}$.

New York State Department of Environmental Conservation, 1999, Part 703 - Surface water and groundwater quality standards and groundwater effluent limitations, chap. $X$ of Division of water: New York State Department of Environmental Conservation regulations Web page, accessed November 14, 2014, at http://www.dec.ny.gov/ regs/4590.html.

New York State Department of Environmental Conservation, 2012, Detailed progress report on activities in 2010 and 2011 to achieve the targets of the 2010-2014 Hudson River estuary action agenda: New York State Department of Environmental Conservation, 85 p., accessed November 14, 2014, at http://www.dec.ny.gov/docs/remediation_hudson pdf/hrepaa1014summ.pdf.

New York State Department of Environmental Conservation, 2014a, Final New York State 2014 Section 303(d) list of impaired waters requiring a TMDL/other strategy: New York State Department of Environmental Conservation, 45 p., accessed December 1, 2014, at http://www.dec. ny.gov/docs/water_pdf/303dlistfinal2014.pdf.
New York State Department of Environmental Conservation, 2014b, Sediment assessment and management: New York State Department of Environmental Conservation Web page, accessed November 14, 2014, at http://www.dec. ny.gov/chemical/28677.html.

New York State Department of Environmental Conservation, 2014c, New York/New Jersey Harbor Contaminant Assessment and Reduction Project: New York State Department of Environmental Conservation Web page, accessed November 14, 2014, at http://www.dec.ny.gov/ chemical/23839.html.

New York State Department of Health, 2014, New York City region fish advisories: New York State Department of Health Web page, accessed November 14, 2014, at http://www.health.ny.gov/environmental/outdoors/fish/ health_advisories/regional/new_york_city.htm.

Redfield, A.C., 1958, The biological control of chemical factors in the environment: American Scientist, v. 46, no. 3, p. 205-221.

Soper, G.A., Fuertes, J.H., Parsons, H.B., Sooysmith, Charles, and Williams, L.R., 1910, Sewerage and sewage disposal in the metropolitan district of New York and New Jersey: Metropolitan Sewerage Commission of New York Report, 550 p., accessed April 12, 2013, at https://archive.org/ details/cu31924004620070.

Stevens Institute of Technology, 2014, NY/NJ harbor estuary surface currents: Stevens Institute of Technology Web page, accessed November 14, 2014, at http://hudson.dl.stevenstech.edu/maritimeforecast/maincontrol.shtml.

U.S. Environmental Protection Agency, 1994, Total maximum daily loads (TMDLS) for copper, mercury, nickel, and lead in the NY-NJ Harbor: U.S. Environmental Protection Agency, $35 \mathrm{p}$.

U.S. Environmental Protection Agency, 2005, Communitybased watershed management-Lessons from the National Estuary Program: U.S. Environmental Protection Agency Handbook EPA-842-B-05-003, 98 p.

U.S. Environmental Protection Agency, 2008, Handbook for developing watershed plans to restore and protect our waters: U.S. Environmental Protection Agency Handbook EPA-841-B-08-002, [variously paged].

U.S. Environmental Protection Agency, [2011], New life for the Bronx and Harlem River watersheds-A comeback through collaboration: U.S. Environmental Protection Agency, 2 p., accessed March 19, 2013, at http://www. urbanwaters.gov/pdf/bronx.pdf. 
U.S. Environmental Protection Agency, 2011, Urban Waters Federal Partnership - Vision, mission, and principles: U.S. Environmental Protection Agency Web page, 3 p., accessed March 19, 2013, at https://www.epa.gov/sites/production/ files/2014-06/documents/urbanwaters-visionv2012.pdf.

U.S. Environmental Protection Agency, 2012a, 5.11, fecal bacteria: U.S. Environmental Protection Agency Web page, accessed November 14, 2014, at https://www.epa.gov/sites/ production/files/2015-06/documents/stream.pdf.

U.S. Environmental Protection Agency, 2012b, Region 22003 NY/NJ harbor data sets: U.S. Environmental Protection Agency Web page, accessed November 14, 2014, at https://archive.epa.gov/emap/archive-emap/web/html/ nynj03.html.

U.S. Environmental Protection Agency, 2012c, National coastal condition report IV: U.S. Environmental Protection Agency, Office of Water and Office of Research and Development, EPA-842-R-10-003, 298 p.

U.S. Environmental Protection Agency, [2013], Biological criteria: U.S. Environmental Protection Agency Web page, accessed May 1, 2013, at http://water.epa.gov/scitech/ swguidance/standards/criteria/aqlife/biocriteria/index.cfm.
U.S. Environmental Protection Agency, [2014a], Combined sewer overflows (CSO) home: U.S. Environmental Protection Agency Web page, accessed November 14, 2014, at https://www.epa.gov/npdes/combined-sewer-overflowscsos.

U.S. Environmental Protection Agency, [2014b], Urban waters - Strategic framework: U.S. Environmental Protection Agency, 9 p., accessed November 14, 2014, at http://www2.epa.gov/urbanwaters/urban-waters-strategicframework.

U.S. Environmental Protection Agency, [2014c], Nutrient and policy data: U.S. Environmental Protection Agency Web page, accessed November 14, 2014, at http://www2.epa. gov/nutrient-policy-data/progress-towards-adopting-totalnitrogen-and-total-phosphorus-numeric-water.

U.S. Geological Survey, 2014, Water data for the nation: U.S. Geological Survey National Water Information System Web site, accessed November 14, 2014, at http://waterdata.usgs. gov/nwis/. 



\section{Appendix 1}

Excel files for the appendix 1 tables are available at http://dx.doi.org/10.3133/sir20165044 
For additional information write to:

Director, New York Water Science Center

U.S. Geological Survey

2045 Route 112, Building 4

Coram, NY 11727

Information requests:

(518) 285-5602

or visit our Web site at:

http://ny.water.usgs.gov

Publishing support by:

The Pembroke and Raleigh Publishing Service Centers 


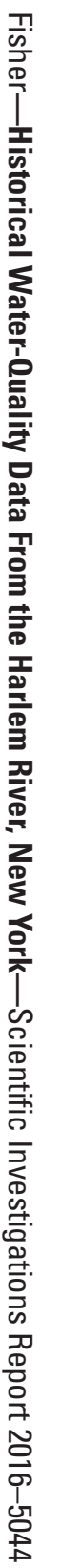

